\title{
Hemarthria compressa-Aspergillus niger-Trichoderma pseudokoningii Mediated Trilateral Perspective for Bioremediation and Detoxification of Industrial Paper Sludge
}

\author{
Sheza Ayaz Khilji ${ }^{1,+}$, Muhammad Aqeel ${ }^{2,+}{ }^{\mathbb{D}}$, Muhammad Faisal Maqsood ${ }^{3}$, Noreen Khalid ${ }^{4}$, Aasma Tufail ${ }^{1}$, \\ Zahoor Ahmad Sajid ${ }^{5}{ }^{\circ}$, Ameena A. Al-Surhanee ${ }^{6}$, Mohamed Hashem ${ }^{7,8}{ }^{\circledR}$, Saad Alamri ${ }^{7}$, \\ Khalid Awadh Al-Mutairi ${ }^{9, *}$ and Ali Noman ${ }^{10, *(1)}$
}

check for updates

Citation: Khilji, S.A.; Aqeel, M.; Maqsood, M.F.; Khalid, N.; Tufail, A.; Sajid, Z.A.; Al-Surhanee, A.A.; Hashem, M.; Alamri, S.; Al-Mutairi, K.A.; et al. Hemarthria compressa-Aspergillus niger-Trichoderma pseudokoningii Mediated Trilateral Perspective for Bioremediation and Detoxification of Industrial Paper Sludge. Sustainability 2021, 13, 12266. https://doi.org/ $10.3390 /$ su132112266

Academic Editors: Kamal H. Shaltout, Ebrahem M. Eid and Tarek M. Galal

Received: 3 October 2021

Accepted: 3 November 2021

Published: 6 November 2021

Publisher's Note: MDPI stays neutral with regard to jurisdictional claims in published maps and institutional affiliations.

Copyright: (c) 2021 by the authors. Licensee MDPI, Basel, Switzerland. This article is an open access article distributed under the terms and conditions of the Creative Commons Attribution (CC BY) license (https:// creativecommons.org/licenses/by/ $4.0 /)$.
1 Division of Science and Technology, Department of Botany, University of Education, Lahore 54770, Pakistan; sheza.ayaz@ue.edu.pk (S.A.K.); aasma.tufail@ue.edu.pk (A.T.)

2 State Key Laboratory of Grassland Agro-Ecosystems, School of Life Sciences, Lanzhou University, Lanzhou 730000, China; aqeelbutt99@gmail.com

3 Department of Botany, University of Agriculture, Faisalabad 38040, Pakistan; faisalmuhammad864@gmail.com

4 Department of Botany, Government College Women University, Sialkot 51310, Pakistan; noreen.khalid@gcwus.edu.pk

5 Department of Botany, University of the Punjab, Lahore 54590, Pakistan; zahoor.botany@pu.edu.pk

6 Biology Department, College of Science, Jouf University, Sakaka 2014, Saudi Arabia; serhanei@ju.edu.sa

7 Department of Biology, Faculty of Science, King Khalid University, Abha 61413, Saudi Arabia; mhashem@kku.edu.sa (M.H.); saadamri@kku.edu.sa (S.A.)

8 Botany and Microbiology Department, Faculty of Science, Assiut University, Assiut 71516, Egypt

9 Biology Department, Faculty of Science, University of Tabuk, Tabuk 71491, Saudi Arabia

10 Department of Botany, Government College University, Faisalabad 38040, Pakistan

* Correspondence: kmutiri@ut.edu.sa (K.A.A.-M.); alinoman@gcuf.edu.pk (A.N.)

+ Khilji, S.A. \& Aqeel, M. contributed equally to this publication.

Abstract: The present study was carried out to evaluate the effects of different fungal species on the metal uptake from paper sludge by Hemarthria compressa L. Paper sludge (PS) in various concentrations $(0,30$ and $60 \%)$ were used with four treatments of two fungal species (F0 = Control, F1 = Aspergillus niger, F2 = Trichoderma pseudokoningii, F3 = A. niger + T. pseudokoningii). Paper sludge as rooting medium steadily influenced growth and physio-biochemical attributes of $H$. compressa in F0. Results revealed discrete variations in growth attributes with different PS concentrations and each fungal treatment. The maximum damages in ionic homeostasis $\left(\mathrm{Na}^{+}, \mathrm{K}^{+}, \mathrm{Ca}^{2+}, \mathrm{Mg}^{2+}\right)$ due to PS toxicity were evident in parallel with declined chlorophyll concentration. The highest growth, total chlorophyll and biomass of the plants were observed when PS was treated with combined fungal strains (F3). Translocation factor decreased with F3 that is indicative of changes in $\mathrm{Cd}, \mathrm{Pb}$, and $\mathrm{Cu}$ movement to shoot from root. The plants with combined fungal treatment also showed greater catalase (CAT), superoxide dismutase (SOD), and peroxidase (POD) activity. Ions, such as $\mathrm{Ca}, \mathrm{Mg}$, and $\mathrm{Na}$, also increased gradually with combined fungal treatment. The correlation matrix displayed a close association among diverse fungal and PS levels with multiple plant attributes. PCA-Biplot confirmed the outcome of correlational analyses among different characters of $H$. compressa. The combined fungal mediate the extraction of heavy metals from the paper sludge by $H$. compressa recommends the high accumulation of heavy metal (HM) and possible reutilization of metal free sludge as a fertilizer, for application in cultivated fields. Furthermore, the effects of fungal species on HM attenuation in PS are linear and can be used in different habitats. Advancement in such research work will also be helpful in understanding the mechanisms and enhancing the ability of other native microbes to remediate metals.

Keywords: Aspergillus niger; microbes; heavy metals; paper sludge; phytoremediation 


\section{Introduction}

Pollution due to heavy metals (HM) is a global issue and levels of contamination vary from place to place. Based on their toxicity in the environment, among all, heavy metals of major concern include $\mathrm{As}, \mathrm{Cd}, \mathrm{Cr}, \mathrm{Cu}, \mathrm{Hg}, \mathrm{Mn}, \mathrm{Ni}, \mathrm{Pb}$, and $\mathrm{Zn}$ [1-3]. Discharge of industrial, municipal and agricultural waste water, and sewage into the rivers has been identified as a significant route of HMs into the aquatic resources [4]. They easily adsorb to suspended particles in water, settle down in the riverbed, and are later released into the water column, where they become a potential secondary source of contamination, threatening ecosystems [5-7]

The paper industry accounts for a significant portion of the global economy in terms of the production value, total wages paid and purchase by consumers. The sludge generated from different sources of paper industries contains various contaminants and toxic metals such as $\mathrm{Pb}, \mathrm{Zn}, \mathrm{Ni}, \mathrm{Cr}, \mathrm{Cd}$, and $\mathrm{Hg}$ [8-10]. This sludge also consists of the raw materials which are used in different manufacturing processes of the paper. Thus, the sludge from the paper industry exhibits great variability in its chemical composition [11]. In general, the sludge is mainly composed of organic matter, several macro/micronutrients, various essential and non-essential trace metals, a variety of microorganisms and organic micropollutants [12,13]. Moreover, it is rich in organic matter and several nutrients needed for plant growth suggesting its use as a fertilizer in the field [14]. Proper use of this sludge enables the valuable nutrients along with organic matter to be recycled. Anaerobic decomposition of the PS may lead to environmental pollution [15].

Microorganisms and plants are commonly used in biological treatment methods for metal remediation [16,17]. Microorganisms are known to develop and adopt different detoxifying mechanisms, e.g., biosorption, bioaccumulation, biotransformation and biomineralization, which can be exploited for bioremediation, either ex situ or in situ [18]. Thus, phytoremediation through hyper-accumulators and biological approaches has been regarded as an ideal remediation technique in soils polluted with heavy metals. Alternately, sustainable biological remediation methods are promising for the removal of heavy metals through highly efficient biosorption and/or hyper-bioaccumulation, which could rectify and re-establish the natural condition of the soil [19-21].

Phytoremediation efficiency of the plants largely depends on their capability to accumulate heavy metals and the total biomass produced by them [22]. Therefore, the plants applied in phytoremediation could accumulate heavy metals in organs and grow on metalliferous soils without suffering phytotoxicity [23]. Previous reports pointed out that several species could be used for the Cr and Cd phytoremediation, such as Leersia hexandra [24], Pluchea indica, Cynodonda dactylon [25,26], Phragmites australis, Typha angustifolia, Typha domingensis [27,28], Jatropha curcas, Pteris vittata [29], and Spartina argentinensis [30]. However, the application of the above metal hyperaccumulator plants is still limited because most metal hyperaccumulator plants grow slowly and their insufficient biomass renders them unfit for phytoremediation.

Hemarthria compressa (L.f.) R. Br. (whip grass) is a stoloniferous perennial tropical grass of family Poaceae. H. compressa is indigenous to Asian temperate and tropical regions [31]. This grass is widely utilized forages in southern China, India, Pakistan, and Bangladesh due to its forage yield and capability of adaptation to hot and humid conditions and for soil conservation under areas of high rainfall [32]. Despite being such an important plant in the ecosystem, it has never been investigated before for its ability to uptake metals from the environment or from the PS. Therefore, current investigation was carried out to evaluate the role of $H$. compressa for its phytoextraction ability and effective translocation of essential ions or HM from paper sludge. This research focused on the isolation of indigenous microbes from the industrial paper sludge and their role in ameliorating the metal stress in plants. 


\section{Materials and Methods}

\subsection{Sampling of Sludge}

Sludge samples were collected from drains of a paper mill industrial area in Sheikhupura, Pakistan. Geographically the sampling site is located at $31^{\circ} 40.404^{\prime} \mathrm{N}$, $074^{\circ} 06.24^{\prime} \mathrm{E}$ and at an altitude of $742 \mathrm{ft}(226 \mathrm{~m}$, Figure 1). Samples of sludge (semisolid form) were collected in air tight plastic bags from a depth of $15 \mathrm{~cm}$, transported to the lab and stored in cold rooms at a temperature of $4{ }^{\circ} \mathrm{C}(277.15 \mathrm{~K})$.

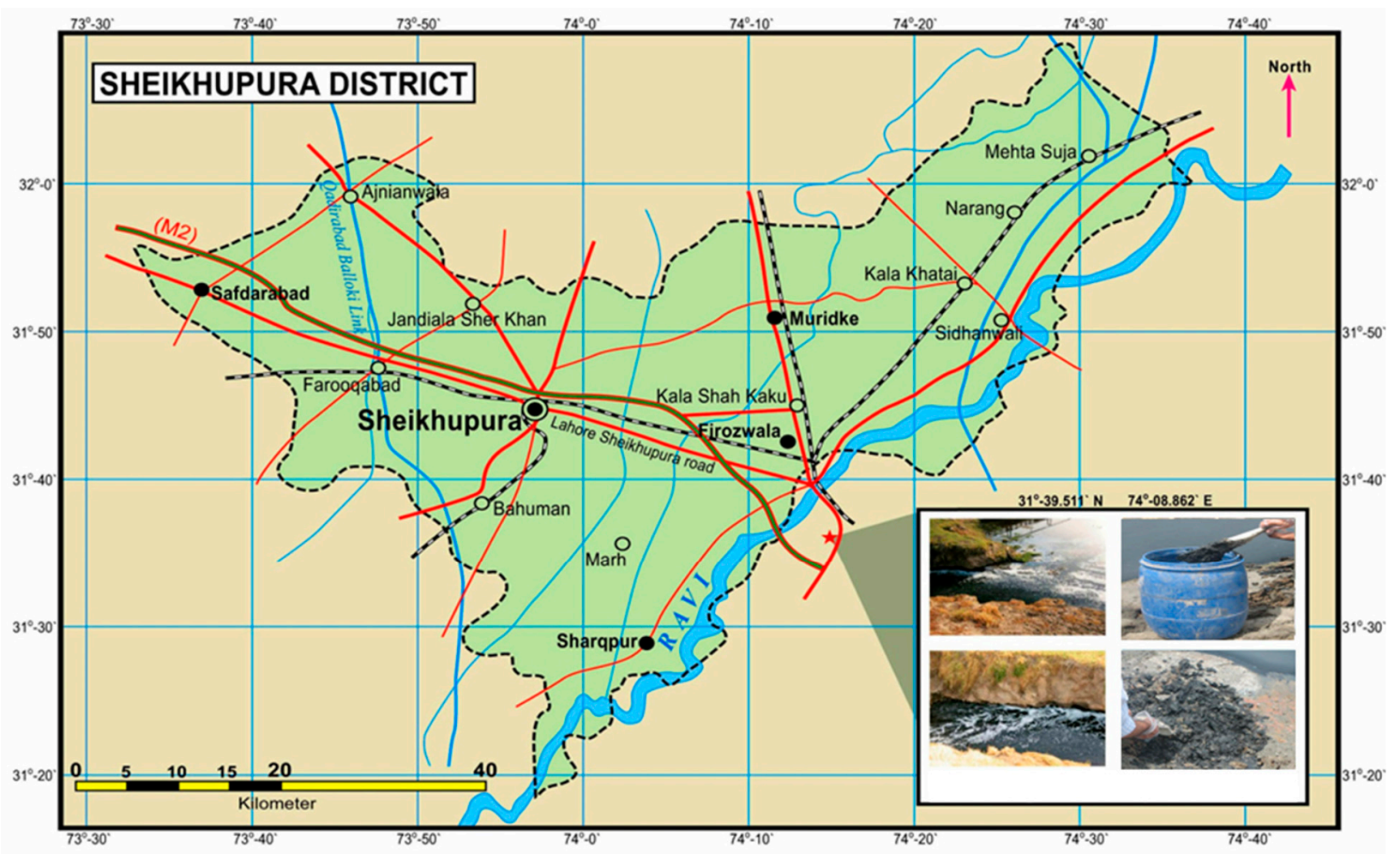

Figure 1. Map of Sheikhupura District, Punjab Province showing the sludge sampling site.

\subsection{Collection of Hydrophytes}

Hemarthria compressa was sampled from heavy metal polluted stagnant ponds along the industrial hub of the Sheikhupura Road (Figure 2a,b). The geographical coordinates for the sampling site were $31^{\circ} 41.868^{\prime} \mathrm{N}, 074^{\circ} 02.038^{\prime} \mathrm{E}$ at an elevation of $666 \mathrm{ft}(202 \mathrm{~m})$. They were uprooted from the substratum, brought to the laboratory in plastic bags. They were then planted in clean water in small tubs and allowed to propagate vegetatively for about 3 months until the tubes were filled with a luxurious growth of these hydrophytes. Mature plants of uniform size and weight were used in different experimental set-up. The ecotypes from polluted habitats were selected to evaluate metal tolerance capability and phytoremediation potential.

\subsection{Establishment of Nurseries}

Nurseries of the transported hydrophytes were raised in a green house in the Department of Botany, University of Education, Township, Lahore. They were then maintained in big plastic pots/tubs, in the wire house, Department of Botany, University of Education, Lahore (Figure 2c; Table 1). 

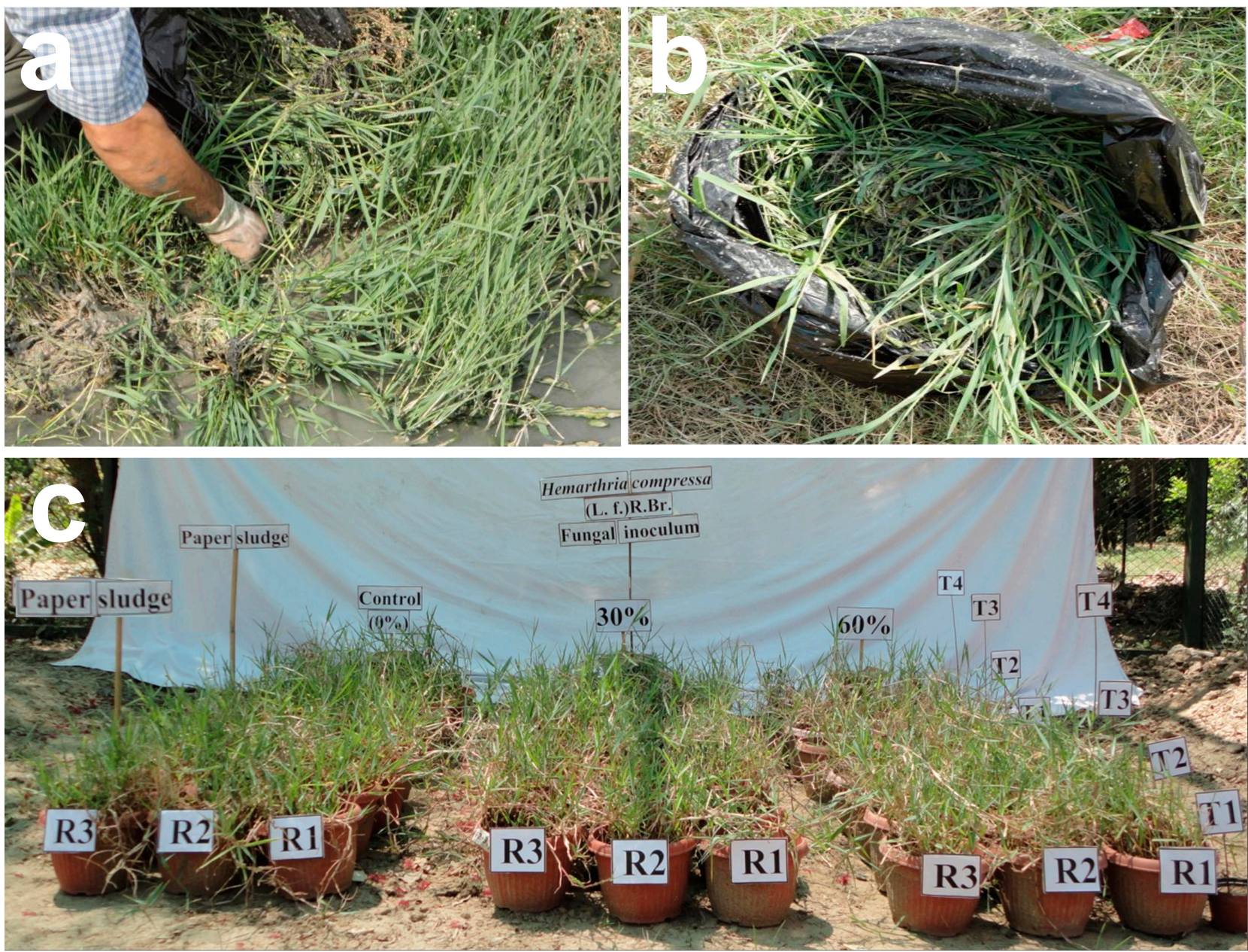

Figure 2. (a-c): Hemarthria compressa (L.f.) R. Br. growing at margins of a pond at industrial site, its collection and experimental arrangement for assessing efficacy of individual and combinatorial fungal treatments in different concentrations of paper sludge.

Table 1. Layout of experimental setup and design.

\begin{tabular}{|c|c|c|c|c|}
\hline \multirow{2}{*}{$\begin{array}{c}\text { Sludge } \\
\text { Concentrations }\end{array}$} & \multicolumn{4}{|c|}{ Treatments } \\
\hline & F0 & F1 & F2 & F3 \\
\hline \multirow{3}{*}{$0 \%$} & R1 & R1 & R1 & $\mathrm{R} 1$ \\
\hline & $\mathrm{R} 2$ & $\mathrm{R} 2$ & $\mathrm{R} 2$ & $\mathrm{R} 2$ \\
\hline & R3 & R3 & R3 & R3 \\
\hline \multirow{3}{*}{$30 \%$} & R1 & R1 & R1 & R1 \\
\hline & $\mathrm{R} 2$ & $\mathrm{R} 2$ & R2 & $\mathrm{R} 2$ \\
\hline & R3 & R3 & R3 & R3 \\
\hline \multirow{3}{*}{$60 \%$} & R1 & R1 & $\mathrm{R} 1$ & $\mathrm{R} 1$ \\
\hline & $\mathrm{R} 2$ & $\mathrm{R} 2$ & $\mathrm{R} 2$ & $\mathrm{R} 2$ \\
\hline & R3 & R3 & R3 & R3 \\
\hline
\end{tabular}

$\overline{\mathbf{F 0}}=$ Tap water without any microbe; $\mathbf{F 1}=$ Aspergillus niger $; \mathbf{F} 2$ = Trichoderma pseudokoningii $; \mathbf{F} 3=$ Aspergillus niger + Trichoderma pseudokoningii. 


\subsection{Isolation of Fungal Strains}

Two fungal species, i.e., Aspergillus niger van Tieg. and Trichoderma pseudokoningii Rifa were isolated from the paper sludge. These fungal strains were cultured on $2 \%$ MEA media (Malt Extract Agar) and preserved in the refrigerator. These fungi were identified and verified from the fungal culture bank of the Institute of Agricultural Sciences (IAGS), University of the Punjab.

\subsection{Experimental Setup and Design}

The preliminary experiment was carried out in small plastic pots with different concentrations of fresh semi-solid (wet) sludge, i.e., $20 \%, 40 \%, 60 \%, 80 \%$, and $100 \%$. Results indicated that at lower concentrations, the plant growth was normal and removal efficiency was higher. At higher concentrations the plants started wilting and removal efficiencies were declined. The rate of decay of plants in higher concentrations was high as compared to lower concentrations of sludge but before the end of the second week, all the plants died completely except control.

The experiment was performed in small plastic pots $(9 \times 15 \mathrm{~cm})$ under open field conditions in a wire-house of the Department of Botany, University Education, Lahore. Three concentrations $(0,30 \%$ and $60 \%)$ of paper sludge were selected for this research work based on preliminary experiments. Four fungal treatments were selected for the final experiment as: $\mathrm{F} 0=$ Control: $\mathrm{F} 1=$ Aspergillus niger: $\mathrm{F} 2=$ Trichoderma pseudokoningii: F3 = Aspergillus niger + Trichoderma pseudokoningii. Three healthy plants of Hemarthria compressa having uniform sizes were grown in each pot. The fungal inoculums $(10 \mathrm{~mL} / \mathrm{pot})$ were applied after every two weeks by following Bareen and Nazir [33]. The metal analysis of paper sludge was carried out before the experiment was set up for each treatment.

The experimental design was a complete randomized design (CRD) with $4 \times 3$ factorial combination of fungal treatment (F0, F1, F2, and F3 as explained above) and paper sludge concentrations $(0,30 \%$ and $60 \%)$. Plants were harvested after 90 days for various growth parameters and heavy metal analysis (Table 1).

\subsection{Physico-Chemical Analyses of Paper Sludge}

Physico-chemical analysis of the collected sludge was performed to find out $\mathrm{pH}$, conductivity, organic matter \%, biochemical oxygen demand (BOD), chemical oxygen demand (COD), anions, and cations (Table 2). The sludge samples (with three replicates) were digested on heating digester (DK 6, Velp, Usmate Velate, Italy), mineralized with aqua-regia (ISO, 1995) and bring final volume up to $50 \mathrm{~mL}$ by adding distilled water.

Hydrogen ion concentration $(\mathrm{pH})$ of the sludge samples was determined using an electrical $\mathrm{pH}$ meter (Ino Lab pH 720, WTW, Burladingen, Germany) by immersing the $\mathrm{pH}$ electrode directly into the sample. Conductivity was measured with the help of an auto ranging portable water proof microprocessor EC meter (HI 9835, HANNA, Nusfalau, Romania). COD of the sample concentrations was determined by the standard method given in Greenburg et al. [34] and BOD was determined by BOD bottles self-check apparatus (BOD Sensor System 10, Velp, Usmate Velate, Italy).

\subsection{Post Harvest Growth and Physico-Chemical Analyses of Plants}

Plant fresh/dry weight, shoot length, total number of roots, and chlorophyll content (Spad-502 Plus, Konica Minolta, Tokyo, Japan) were recorded for each treatment. The plants were kept in an oven at $70^{\circ} \mathrm{C}$ for $36 \mathrm{~h}$. For trace metal estimation, digestion apparatus (TMD 10, Velp, Usmate Velate, Italy) was used following the method of Greenburg, Clesceri and Eaton [34]. The dried plant material (roots and shoots) were ground into a fine powder using electric grinder. Acid digestion of this grounded plant material with $\mathrm{HNO}_{3}$ and $\mathrm{HClO}_{4}(1: 4)$ was performed with a digestion and mineralization apparatus (TMD 10, Velp, Usmate Velate, Italy) by following the method of Wolf [35]. 
Table 2. Physico-chemical and metal analysis of different concentrations of paper sludge (PS) before introducing plants.

\begin{tabular}{ccccc}
\hline Parameters & $\begin{array}{c}\mathbf{0} \% \\
\text { (TW Only) }\end{array}$ & $\begin{array}{c}\mathbf{3 0 \%} \\
\text { (TW + PS) }\end{array}$ & $\begin{array}{c}\mathbf{6 0} \% \\
\text { (TW + PS) }\end{array}$ & $\begin{array}{c}\mathbf{1 0 0 \%} \\
\text { (PS Only) }\end{array}$ \\
\hline $\mathrm{pH}$ & $7.29 \pm 0.06^{\mathrm{d}}$ & $8.20 \pm 0.02^{\mathrm{c}}$ & $8.71 \pm 0.06^{\mathrm{b}}$ & $8.87 \pm 0.04^{\mathrm{a}}$ \\
\hline $\begin{array}{c}\text { Conductivity } \\
(\mathrm{mS} / \mathrm{cm})\end{array}$ & $0.295 \pm 0.01^{\mathrm{d}}$ & $5.34 \pm 0.05^{\mathrm{c}}$ & $5.11 \pm 2.6^{\mathrm{b}}$ & $5.45 \pm 0.06^{\mathrm{a}}$ \\
\hline Chlorides (mg/L) & $30 \pm 0.43^{\mathrm{d}}$ & $256 \pm 0.36^{\mathrm{c}}$ & $371 \pm 0.64^{\mathrm{b}}$ & $423 \pm 0.75^{\mathrm{a}}$ \\
\hline $\mathrm{BOD}(\mathrm{mg} / \mathrm{L})$ & $110 \pm 0.26^{\mathrm{c}}$ & $150 \pm 0.04^{\mathrm{bc}}$ & $190 \pm 0.11^{\mathrm{b}}$ & $250 \pm 0.03^{\mathrm{a}}$ \\
\hline $\mathrm{COD}(\mathrm{mg} / \mathrm{L})$ & $200 \pm 0.06^{\mathrm{d}}$ & $1200 \pm 0.12^{\mathrm{c}}$ & $1700 \pm 0.07^{\mathrm{b}}$ & $1600 \pm 0.05^{\mathrm{a}}$ \\
\hline $\mathrm{Ca}(\mathrm{mg} / \mathrm{L})$ & $80 \pm 0.17^{\mathrm{d}}$ & $1852 \pm 1.53^{\mathrm{c}}$ & $2059 \pm 1.68^{\mathrm{b}}$ & $2344 \pm 1.77^{\mathrm{a}}$ \\
\hline $\mathrm{K}(\mathrm{mg} / \mathrm{L})$ & $12 \pm 0.1^{\mathrm{d}}$ & $935 \pm 0.68^{\mathrm{c}}$ & $1050 \pm 1.10^{\mathrm{b}}$ & $1322 \pm 2.33^{\mathrm{a}}$ \\
\hline $\mathrm{Na}(\mathrm{mg} / \mathrm{L})$ & $145 \pm 0.36^{\mathrm{d}}$ & $1210 \pm 0.45^{\mathrm{c}}$ & $1522 \pm 0.30^{\mathrm{b}}$ & $1820 \pm 0.42^{\mathrm{a}}$ \\
\hline $\mathrm{Mg}(\mathrm{mg} / \mathrm{L})$ & $20 \pm 0.16^{\mathrm{d}}$ & $80 \pm 0.33^{\mathrm{c}}$ & $104 \pm 0.40^{\mathrm{b}}$ & $156 \pm 0.02^{\mathrm{a}}$ \\
\hline $\mathrm{Cd}(\mathrm{mg} / \mathrm{L})$ & $\mathrm{ND}$ & $934 \pm 0.24^{\mathrm{c}}$ & $1143 \pm 0.53^{\mathrm{b}}$ & $1422 \pm 0.23^{\mathrm{a}}$ \\
\hline $\mathrm{Cu}(\mathrm{mg} / \mathrm{L})$ & $\mathrm{ND}$ & $2168 \pm 1.53^{\mathrm{c}}$ & $2529 \pm 1.15^{\mathrm{b}}$ & $2933 \pm 2.12^{\mathrm{a}}$ \\
\hline $\mathrm{Pb}(\mathrm{mg} / \mathrm{L})$ & $\mathrm{ND}$ & $1026 \pm 0.40^{\mathrm{c}}$ & $1887 \pm 1.10^{\mathrm{b}}$ & $2213 \pm 0.21^{\mathrm{a}}$ \\
\hline Organic matter $(\%)$ & $\mathrm{ND}$ & $23.10 \pm 0.10^{\mathrm{c}}$ & $37.14 \pm 0.03^{\mathrm{bc}}$ & $42.23 \pm 0.07^{\mathrm{a}}$ \\
\hline
\end{tabular}

The values given above indicate mean $\pm \mathrm{SE}(n=3)$. Different letters within each row indicate significant differences at $p \leq 0.05$ (Duncan's multiple range test). Values with the same letter within each row are not significantly different. PS = Fresh semi-solid paper sludge; TW = Tap water; $\mathbf{0} \%=$ Tap Water only; $\mathbf{3 0} \%=300 \mathrm{~g}$ sludge mixed in $1000 \mathrm{~mL}$ of tap water; $\mathbf{6 0} \%=600 \mathrm{~g}$ sludge in $1000 \mathrm{~mL}$ of tap water; $\mathbf{1 0 0} \%=\mathrm{PS}$ only).

\subsection{Elemental Quantification}

For the analysis of different ions, the samples (sludge amendments and plants) were analyzed on a Flame photometer (PFP7, JENWAY, Staffordshire, UK) while the determination of heavy metals was done on an Atomic Absorption Spectrophotometer (GBC SAVANT AA, Braeside, Australia). A Flame photometer (JENWAY PFP 7) was used to determine $\mathrm{Na}, \mathrm{Ca}$ and $\mathrm{K}$. The concentrations of $\mathrm{Mg}, \mathrm{Cd}, \mathrm{Cu}$ and $\mathrm{Pb}$ were assessed by employing an atomic absorption spectrophotometer (GBC SAVANT AA, Braeside, Australia). The spectrophotometer was calibrated for each element using standard solutions of known concentration before the sample injection. Contents were expressed as $\mathrm{mg} \mathrm{L}^{-1}$ for sludge samples and $\mathrm{mg} \mathrm{kg}^{-1}$ for plant samples.

\subsection{Antioxidants}

Fresh leaf material $(0.25 \mathrm{~g})$ was homogenized in $5 \mathrm{~mL}$ potassium phosphate buffer with $7.8 \mathrm{pH}$. The extract was subjected to centrifugation for $15 \mathrm{~min}$ at 12,000 $\mathrm{rpm}$. The resultant supernatant was placed at $-20^{\circ} \mathrm{C}$ for further analysis of catalase, peroxidase and superoxide dismutase.

\subsubsection{Superoxide Dismutase (SOD)}

Superoxide dismutase activity was recorded through photoreduction inhibition of NBT by following the method of Giannopolitis and Ries [36]. Potassium phosphate buffer $(1 \mathrm{~mL})$, NBT $(50 \mu \mathrm{L})$, distilled water $(400 \mu \mathrm{L})$, L-methionine $(0.1 \mathrm{~mL})$, triton-X $(0.1 \mathrm{~mL})$, riboflavin $(50 \mu \mathrm{L})$ and sample extract $(50 \mu \mathrm{L})$ were placed in light for $15 \mathrm{~min}$ and absorbance of each sample was recorded at $560 \mathrm{~nm}$ using a spectrophotometer.

\subsubsection{Catalase (CAT)}

Chance and Maehly [37] protocol was used to find the activity of catalase. Sample extract $(0.1 \mathrm{~mL})$, potassium phosphate buffer $(1.9 \mathrm{~mL})$ and $\mathrm{H}_{2} \mathrm{O}_{2}(1 \mathrm{~mL})$ were mixed in a 
cuvette and absorbance of this reaction mixture was recorded at $240 \mathrm{~nm}$ with $30 \mathrm{~s}$ interval for 2 min with a spectrophotometer.

\subsubsection{Peroxidase (POD)}

The activity of peroxidase was recorded by following the Chance and Maehly [37] method. A reaction mixture of $1 \mathrm{~mL}$ was prepared by adding sample extract $(0.05 \mathrm{~mL})$, guaiacol $(0.1 \mathrm{~mL}), \mathrm{H}_{2} \mathrm{O}_{2}(0.1 \mathrm{~mL})$ and phosphate buffer $(0.75 \mathrm{~mL})$ in a cuvette. Then, absorbance of each sample was recorded at $470 \mathrm{~nm}$ with $20 \mathrm{~s}$ interval for $2 \mathrm{~min}$.

\subsubsection{Malondialdehyde (MDA)}

A total of $0.25 \mathrm{~g}$ fresh leaf material was homogenized at $4{ }^{\circ} \mathrm{C}$ in $3 \mathrm{~mL}, 1 \% \mathrm{w} / \mathrm{v}$ tricarboxylic acid following the Cakmak and Horst [38] technique and extract was centrifuged at $12,000 \mathrm{rpm}$ for $15 \mathrm{~min}$. Twenty percent TCA was prepare to make thiobarbituric acid $(0.5 \% \mathrm{v} / \mathrm{v})$ and $4 \mathrm{~mL}$ of this solution was added to $1 \mathrm{~mL}$ supernatant. The resultant mixture was allowed to heat for $90 \mathrm{~min}$ in a water bath and then immediately cooled in ice. The absorbance of each sample was recorded at 532 and $600 \mathrm{~nm}$ through spectrophotometer by using 5\% carboxylic acid as blank.

\subsection{Translocation Factor (TF), Enrichment Coefficient (EC), and Biological Concentration Factor (BCF)}

$\mathrm{TF}, \mathrm{EC}$, and BCF are considered for evaluating a plant as hyperaccumulator of a metal and having potential for phytoremediation [39]. TF is a ratio of heavy metals in plant shoot to that in plant root $[1,39]$. EC depicts the heavy metal element concentration in above-ground plant part (shoot) divided by this heavy metal element concentration in the soil [40]. BCF is the ratio of heavy metal concentration in root to that in soil $[39,41]$.

\subsection{Statistical Analyses}

Statistical data analysis was executed with ANOVA using Costat (version 6.2, Cohorts Software, 2003, Monterey, CA, USA) and Duncan's multiple range test (DMRT) was used to compare means [42,43]. Visualization (Graphs, Correlation matrix and PCA biplot) was done using the statistical program " $\mathrm{R}$ (v 4.0.4)" [44].

\section{Results}

\subsection{Physico-Chemical Analysis of Paper Sludge}

A comparison $(p<0.05)$ of physico-chemical investigation of different concentrations of paper sludge (PS) used in this study revealed that $60 \%$ sludge concentration appeared to be the most toxic in comparison with $30 \%$ PS. The overall highest levels of pH (8.71), conductivity $(5.34 \mathrm{mS} / \mathrm{cm})$ and chlorides $(371 \mathrm{mg} / \mathrm{L})$ were observed in $60 \%$ concentration of paper sludge. Biological oxygen demand $(190 \mathrm{mg} / \mathrm{L})$ and chemical oxygen demand $(1700 \mathrm{mg} / \mathrm{L})$ were also recorded highest in $60 \%$ PS. Additionally, heavy metal $(\mathrm{Cd}, \mathrm{Cu}$ and $\mathrm{Pb}$ ) contents were also quite high in $60 \%$ concentration of sludge. The organic matter in $60 \%$ concentration of PS was maximum i.e., $37.14 \%$ and the minimum value was observed in $30 \%$ PS $(23.10 \%$, Table 2$)$.

\subsection{Shoot Length}

Application of $30 \%$ and $60 \%$ paper sludge (PS) significantly declined the shoot length (SL) in Hemarthria compressa plants in the absence of fungal strains (F0). However, inoculation of fungal strains, i.e., F1 (Aspergillus niger) supported up to 7\% increase in the shoot length in 60\% PS concentration while F2 (Trichoderma pseudokoningii) exerted a rise of $22.8 \%$ in $30 \%$ PS application $(p<0.05)$. However, combined inoculation of $A$. niger and T. pseudokoningii (F3) significantly decreased the length of shoot under control and both PS applications. Under control conditions, F1 and F2 strains enhanced the shoot length up to $20.4 \%$ and $16.1 \%$, respectively. Maximum shoot length was observed in $30 \%$ PS treated plants with the inoculation of T. pseudokoningii $(p<0.05)$ (Table 3). 
Table 3. Various morphological parameters observed in 90 days old plants of Hemarthria compressa L. grown at different concentrations of paper sludge containing fungi.

\begin{tabular}{|c|c|c|c|c|c|}
\hline \multirow{2}{*}{ Parameter } & \multirow{2}{*}{ Conc. of PS } & \multicolumn{4}{|c|}{ Treatments of Fungal Strains } \\
\hline & & F0 & F1 & F2 & F3 \\
\hline \multirow{3}{*}{$\begin{array}{l}\text { Shoot length } \\
(\mathrm{cm})\end{array}$} & $0 \%$ & $9.3 \pm 0.01^{\mathrm{aC}}$ & $11.2 \pm 0.09^{\mathrm{aA}}$ & $10.8 \pm 0.06^{\mathrm{aB}}$ & $8.7 \pm 0.03^{\mathrm{aDE}}$ \\
\hline & $30 \%$ & $8.3 \pm 0.07^{b C}$ & $8.8 \pm 0.03^{\mathrm{cC}}$ & $10.2 \pm 0.03^{\mathrm{abA}}$ & $7.2 \pm 0.37^{\mathrm{bD}}$ \\
\hline & $60 \%$ & $8.5 \pm 0.07^{\mathrm{bB}}$ & $9.1 \pm 0.01^{\mathrm{bA}}$ & $8.2 \pm 0.03^{\mathrm{bB}}$ & $6.3 \pm 0.07^{\mathrm{cD}}$ \\
\hline \multirow{3}{*}{ No. of roots } & $0 \%$ & $10 \pm 0.02^{a B}$ & $6 \pm 0.04^{b D}$ & $8 \pm 0.05^{b C}$ & $12 \pm 0.03^{\mathrm{aA}}$ \\
\hline & $30 \%$ & $7 \pm 0.04^{\mathrm{bB}}$ & $6 \pm 0.04^{b C}$ & $7 \pm 0.03^{\mathrm{cB}}$ & $9 \pm 0.01^{\mathrm{bA}}$ \\
\hline & $60 \%$ & $5 \pm 0.04^{\mathrm{cD}}$ & $7 \pm 0.02^{\mathrm{aC}}$ & $9 \pm 0.01^{\mathrm{aB}}$ & $11 \pm 0.04^{\mathrm{aA}}$ \\
\hline \multirow{3}{*}{$\begin{array}{c}\text { Fresh weight } \\
(\mathrm{g})\end{array}$} & $0 \%$ & $2.70 \pm 0.01^{\mathrm{aC}}$ & $3.03 \pm 0.04^{\mathrm{aB}}$ & $3.06 \pm 0.03^{\mathrm{aB}}$ & $3.12 \pm 0.06^{\mathrm{aA}}$ \\
\hline & $30 \%$ & $2.0 \pm 0.03^{b C}$ & $2.02 \pm 0.01^{\mathrm{bB}}$ & $2.06 \pm 0.05^{\mathrm{bB}}$ & $3.0 \pm 0.07^{\mathrm{abA}}$ \\
\hline & $60 \%$ & $1.8 \pm 0.05^{\mathrm{cC}}$ & $1.7 \pm 0.06^{\mathrm{cC}}$ & $1.10 \pm 0.01^{\mathrm{cAB}}$ & $1.12 \pm 0.02^{\mathrm{cAB}}$ \\
\hline \multirow{3}{*}{$\begin{array}{l}\text { Dry weight } \\
(\mathrm{g})\end{array}$} & $0 \%$ & $1.92 \pm 0.01^{\mathrm{aCD}}$ & $1.85 \pm 0.03^{\mathrm{aCD}}$ & $2.58 \pm 0.02^{\mathrm{aB}}$ & $2.74 \pm 0.09^{\mathrm{aA}}$ \\
\hline & $30 \%$ & $1.62 \pm 0.05^{\mathrm{bC}}$ & $1.43 \pm 0.06^{\mathrm{bD}}$ & $1.48 \pm 0.04^{b D}$ & $1.54 \pm 0.07^{b E}$ \\
\hline & $60 \%$ & $1.35 \pm 0.08^{\mathrm{cC}}$ & $1.23 \pm 0.05^{\mathrm{cD}}$ & $1.37 \pm 0.07^{\mathrm{bcB}}$ & $1.45 \pm 0.06^{\mathrm{bcA}}$ \\
\hline
\end{tabular}

The values given above indicate mean $\pm \operatorname{SD}(n=9)$. Statistically significant differences (between concentrations) are indicated by lowercase letters within columns and differences (between treatments) indicated by capital letters within rows. Values with the same letter are not significantly different according to Duncan's multiple range test at $p \leq 0.05$. F0 = Control, F1 = Aspergillus niger, F2 = Trichoderma pseudokoningii, F3 = Aspergillus niger + Trichoderma pseudokoningii.

\subsection{Number of Roots}

Exposure of $H$. compressa to $30 \%$ and $60 \%$ PS concentrations prominently caused a $30 \%$ and $60 \%$ reduction in number of roots, respectively. A clear surge of $20 \%, 28.5 \%$ and $120 \%$ was observed in root number when plants were exposed to F3 treatment under $0 \%, 30 \%$ and $60 \%$ PS concentrations $(p<0.05)$, respectively. Inoculation of F1 and F2 treatments in plants subjected to $60 \%$ PS expressed enhanced root number to $16.6 \%$ and $12.5 \%$ respectively. With $30 \%$ PS concentration, F1 treatment exhibited a non-significant effect while, F2 treatment lessened the root number up to $12.5 \%$. The highest number of roots was observed under F3 treatment in the absences of sewage sludge application $(p<0.05)$ (Table 3$)$.

\subsection{Fresh and Dry Weight}

Paper sludge application significantly reduced the fresh weigh in $H$. compressa plants both under control and all fungal treatments. A decrease of 33.3\%, 43.8\%, 64\% and $64.5 \%$ in fresh weight was recorded under F0, F1, F2 and F3 treatments, respectively, in 60\% PS concentration $(p<0.05)$. Exposure to F3 treatment enhanced the fresh weight up to $15.5 \%$ and $50 \%$ under both $0 \%$ and 30\% PS concentration respectively. Maximum and minimum fresh weights were observed in $0 \%$ and $60 \%$ PS concentration with the respective inoculation of F3 and F2 treatments $(p<0.05)$ (Table 3).

In the absence of fungal species, dry weight of $H$. compressa plants showed a $15.6 \%$ and $29.6 \%$ decrease when exposed to $30 \%$ and $60 \%$ PS concentration. Inoculation of fungal species (F1, F2, and F3 treatments) also abridged the dry weight under both the concentrations of PS. However, combined application of A. niger and T. pseudokoningii (F3) improved up to $7.5 \%$, the dry weight of plants irrigated with $60 \%$ PS concentration $(p<0.05)$. The F2 and F3 treatments, significantly enhanced the dry weight up to $34.7 \%$ and $42.7 \%$ in the absence of PS. Maximum dry weight was observed with the inoculation of F3 treatment under control conditions (Table 3). 


\subsection{Total Chlorophyll Contents (SPAD Value)}

The amount of total chlorophyll contents after 30-, 60- and 90-day intervals was significantly improved with the inoculation of F1, F2 and F3 treatments under control and both PS concentrations (30\% and 60\%). Inoculation of F3 treatment, significantly boosted the total chlorophyll contents than F1 and F2 in 30 days old plants, but maximum increase was observed in the absence of PS application. However, F2 treatment was more effective under 60\% PS application. In 60- and 90-day-old plants, F1, F2 and F3 treatments considerably enhanced the total chlorophyll contents under control and $30 \%, 60 \%$ and PS application, respectively (Figure 3).
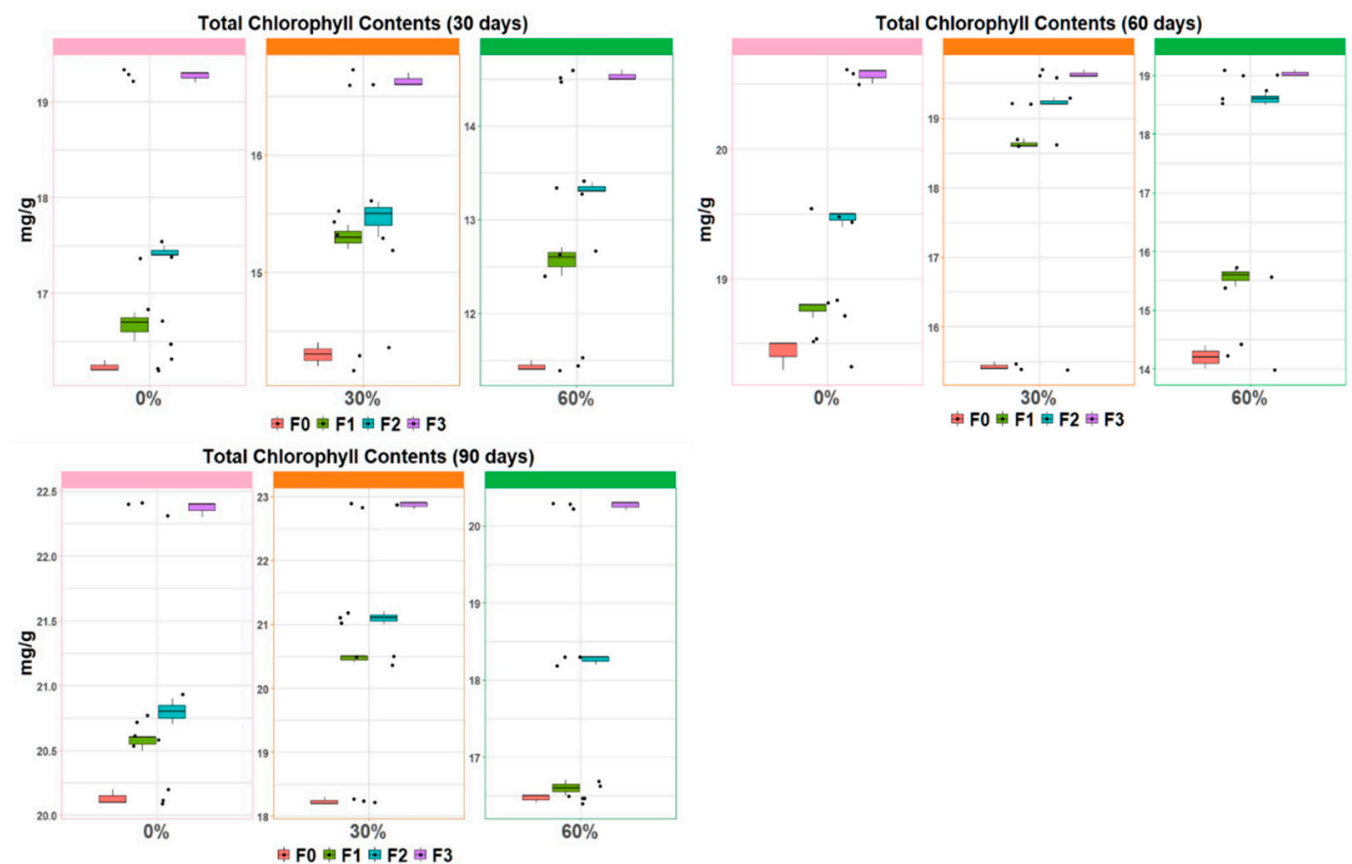

Figure 3. Total chlorophyll contents (SPAD) of $H$. compressa plants after 30, 60, and 90 days post treatment. The values given above indicate mean of 9 replicates. F0 $=$ Control, $\mathbf{F} \mathbf{1}=$ Aspergillus niger, F2 = Trichoderma pseudokoningii, F3 = Aspergillus niger + Trichoderma pseudokoningii.

\subsection{Root and Shoot Cadmium}

Application of PS significantly enhanced the root and shoot cadmium (Cd) in $\mathrm{H}$. compressa plants. Inoculation of all the fungal treatments also augmented the Cd contents in both root and shoot. The F3 treatment displayed more $\mathrm{Cd}$ accumulation in both root and shoot under $30 \%$ and $60 \%$ PS application. The lowest amount of Cd was recorded under F1 treatment in 30\% PS application in both root and shoot. The shoot presented more Cd accretion as compared to root (Figure $4 \mathrm{a}$ ). 


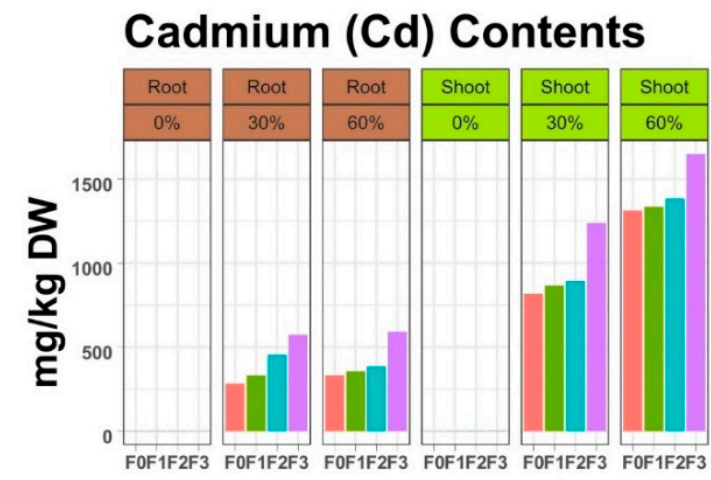

\section{Lead $(\mathrm{Pb})$ Contents}
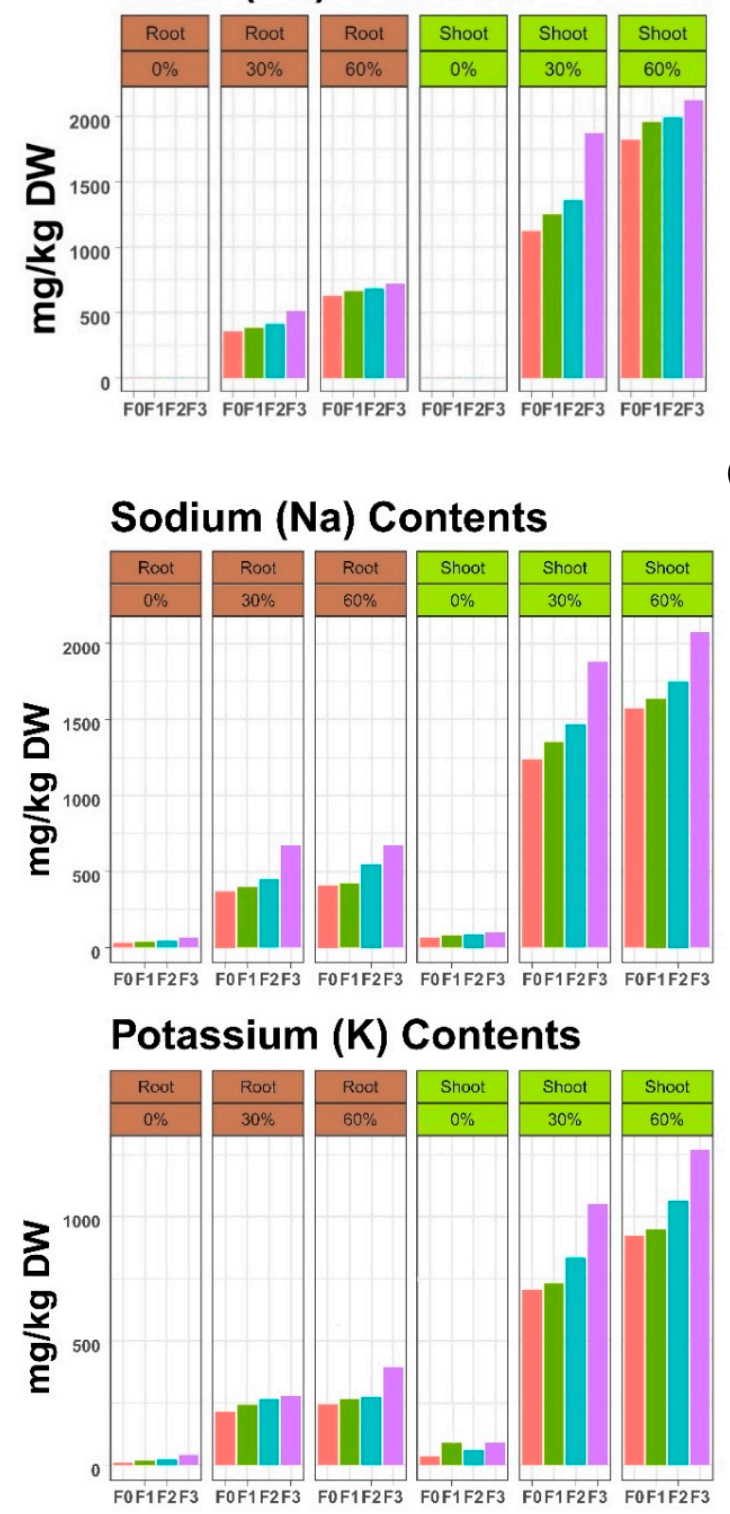

(b)

\section{Copper(Cu) Contents}
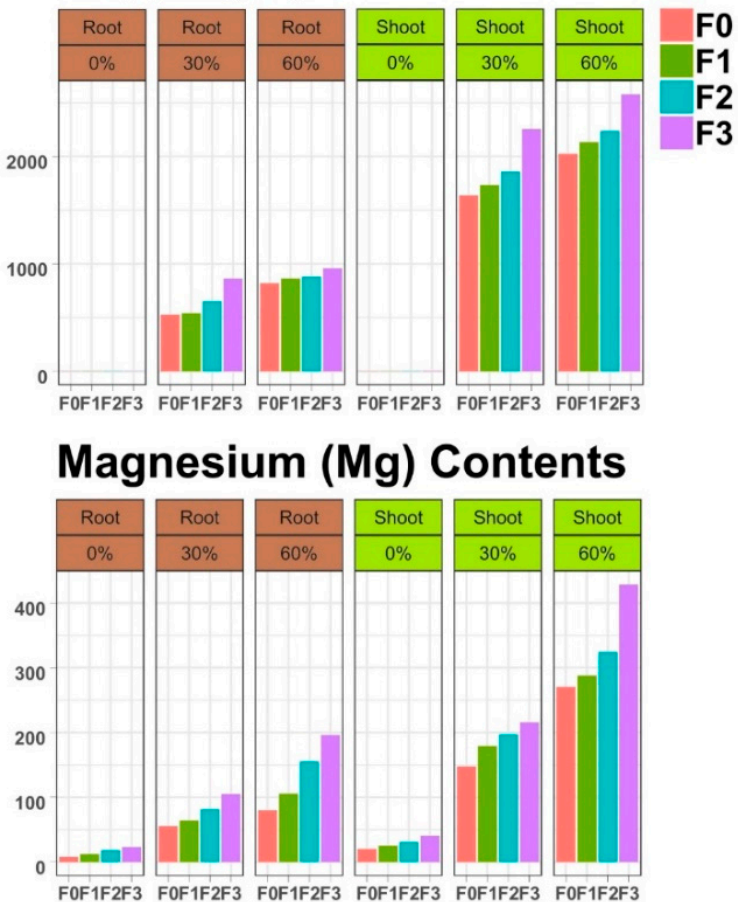

(a)

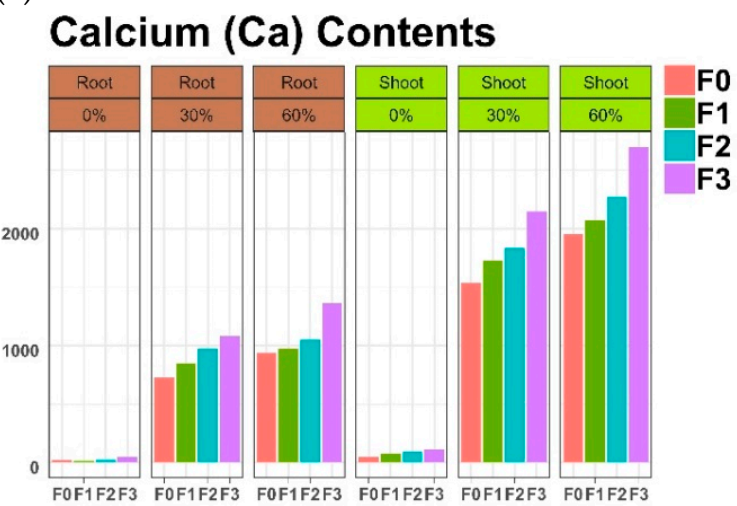

Figure 4. Quantification of (a) Cadmium, Copper, Lead, and Magnesium, (b) Sodium, Calcium, and Potassium in dried tissues of $H$. compressa plants after $0,30 \%$ and $60 \%$ PS treatment with and without fungal application. The values given above indicate mean of 9 replicates. F0 = Control, F1 = Aspergillus niger, F2 = Trichoderma pseudokoningii, F3 = Aspergillus niger + Trichoderma pseudokoningii. 


\subsection{Root and Shoot Copper}

The amount of copper $(\mathrm{Cu})$ also increased when plants were exposed to $30 \%$ and $60 \%$ PS and this increase was more prominent in shoot as compared to root. In root, F3 treatment noticeably enhanced the $\mathrm{Cu}$ contents as compared to other treatments in $30 \%$ PS application. However, under 60\% PS application, all the treatments (F0, F1, F2 and F3) showed comparable increase in Cu contents. In case of shoot, exposure $30 \%$ and $60 \%$ PS significantly enhanced the $\mathrm{Cu}$ contents and this increase was more significant when F3 treatment was applied. Maximum $\mathrm{Cu}$ was recorded in shoot under 60\% PS application with the inoculation of F3 treatment (Figure 4a).

\subsection{Root and Shoot Lead}

Exposure of $H$. compressa plants to PS (30\% and 60\%) significantly increased the lead $(\mathrm{Pb})$ uptake in both root and shoot. This increase was high under $60 \%$ PS application as compared to $30 \%$ PS in both root and shoot. Minimum lead uptake was observed in F0 ( $0 \%$ PS) treatment. In the $60 \%$ PS application, all the treatments showed similar Pb uptake in root. Inoculation of $\mathrm{F} 3$ treatment, enhanced the $\mathrm{Pb}$ contents in shoot but this increase was more under $60 \%$ PS application as compared to $30 \%$ PS. The most significant Pb uptake was recorded in shoot under 60\% PS application (Figure 4a).

\subsection{Root and Shoot Magnesium}

A substantial increase in magnesium was observed in both root and shoot with the application of PS but this increase was more in shoot when $60 \%$ was applied. The highest value for both root and shoot magnesium was observed when $60 \%$ PS was applied in the presence of both A. niger and T. pseudokoningii (F3). Application of F1 (Aspergillus niger) caused a significant decrease in both root and shoot magnesium under both 30 and $60 \%$ PS application (Figure 4a).

\subsection{Root and Shoot Sodium}

Application of both $30 \%$ and $60 \%$ PS treatment considerably enhanced the sodium $\left(\mathrm{Na}^{+}\right)$content in both root and shoot as compared to control plants. This significant increase in $\mathrm{Na}^{+}$was more in shoot compared to the root. Maximum $\mathrm{Na}^{+}$was observed in F3 treatment in both root and shoot of $H$. compressa plants. Of all the applied treatments, F1 (Aspergillus niger) showed a considerable decrease in both root and shoot $\mathrm{Na}^{+}$under both $30 \%$ and $60 \%$ PS application (Figure $4 \mathrm{~b}$ ).

\subsection{Calcium and Potassium in Root and Shoot}

The amount of calcium $\left(\mathrm{Ca}^{2+}\right)$ and potassium $\left(\mathrm{K}^{+}\right)$was significantly improved with the application of PS application both in root and plant shoot. This increment $(p<0.05)$ in $\mathrm{Ca}^{2+}$ and $\mathrm{K}+$ was more pronounced under $60 \%$ PS application compared to $30 \%$. Inoculation of different fungal species significantly increased the $\mathrm{Ca}^{2+}$ and $\mathrm{K}^{+}$level but this increase was maximum when F3 treatment was applied in both root and shoot of H. compressa plants. The highest level of $\mathrm{Ca}^{2+}$ was observed in plant shoot when $60 \% \mathrm{PS}$ was applied in combination with F3 treatment (Figure 4 b).

\subsection{Translocation Factor (TF), Enrichment Coefficient (EC), and Biological Concentration Factor (BCF)}

The values of TF, EC, and BCF above 1 shows the high ability of the plant to absorb, translocate, and accumulate heavy metals in its body (Table 4). In general, all the fungal strains positively and significantly impacted Hemarthria compressa by enhancing the metal ions in tissues, however, the fungal treatment F3 had the most pronounced effect in increasing the values of TF, EC, and BCF. 
Table 4. Translocation factor (TF), enrichment coefficient (EC) and bio-concentration factor (BCF) of metals and mineral ions in 90 days old plant of Hemarthria compressa L. grown at different concentrations of paper sludge containing fungal strains.

\begin{tabular}{|c|c|c|c|c|c|c|c|c|c|c|c|c|c|}
\hline \multirow[t]{2}{*}{ Ions } & \multirow[t]{2}{*}{ PS Concentration } & \multicolumn{4}{|c|}{ Translocation Factor (TF) } & \multicolumn{4}{|c|}{ Enrichment Coefficient (EC) } & \multicolumn{4}{|c|}{$\begin{array}{l}\text { Bio-Concentration Factor } \\
\text { (BCF) }\end{array}$} \\
\hline & & F0 & F1 & F2 & F3 & F0 & F1 & F2 & F3 & F0 & F1 & F2 & F3 \\
\hline \multirow{3}{*}{$\mathrm{Ca}$} & $0 \%$ & 2.44 & 3.33 & 3.66 & 2.32 & 0.55 & 0.87 & 1.11 & 1.33 & 0.77 & 1.06 & 1.40 & 1.91 \\
\hline & $30 \%$ & 2.07 & 2.03 & 1.88 & 1.98 & 0.81 & 0.93 & 0.99 & 1.16 & 1.20 & 1.38 & 1.51 & 1.74 \\
\hline & $60 \%$ & 2.09 & 2.11 & 2.15 & 1.95 & 0.94 & 1.00 & 1.10 & 1.30 & 1.40 & 1.47 & 1.61 & 1.97 \\
\hline \multirow{3}{*}{ K } & $0 \%$ & 3.5 & 2.5 & 2.60 & 2.2 & 2.91 & 3.75 & 5.00 & 7.33 & 3.75 & 5.25 & 6.91 & 10.66 \\
\hline & $30 \%$ & 3.25 & 3.09 & 3.16 & 3.77 & 0.75 & 0.77 & 0.89 & 1.11 & 0.98 & 1.01 & 1.18 & 1.41 \\
\hline & $60 \%$ & 3.71 & 3.57 & 3.83 & 3.20 & 0.86 & 0.9 & 1.01 & 1.20 & 1.1 & 1.15 & 1.27 & 1.58 \\
\hline \multirow{3}{*}{$\mathrm{Na}$} & $0 \%$ & 1.5 & 1.60 & 1.54 & 1.49 & 0.43 & 0.53 & 0.58 & 0.68 & 0.65 & 0.80 & 0.90 & 1.15 \\
\hline & $30 \%$ & 3.24 & 3.46 & 3.26 & 2.80 & 1.01 & 1.11 & 1.21 & 1.55 & 1.32 & 1.43 & 1.58 & 2.10 \\
\hline & $60 \%$ & 3.87 & 3.87 & 3.23 & 3.09 & 1.04 & 1.07 & 1.15 & 1.36 & 1.31 & 1.35 & 1.50 & 1.80 \\
\hline \multirow{3}{*}{$\mathrm{Mg}$} & $0 \%$ & 1.42 & 1.52 & 1.60 & 1.42 & 1.5 & 1.9 & 2.25 & 2.5 & 1.4 & 1.8 & 2.4 & 3.1 \\
\hline & $30 \%$ & 2.67 & 2.80 & 2.47 & 2.00 & 1.87 & 2.23 & 2.47 & 2.63 & 2.575 & 3.037 & 3.475 & 3.95 \\
\hline & $60 \%$ & 3.41 & 2.70 & 2.08 & 2.18 & 2.62 & 2.75 & 3.12 & 4.16 & 3.39 & 3.77 & 4.62 & 6.06 \\
\hline \multirow{3}{*}{$\mathrm{Cd}$} & $0 \%$ & 3.33 & 3.5 & 3.29 & 3.03 & 0 & 0 & 0 & 0 & 0 & 0 & 0 & 0 \\
\hline & $30 \%$ & 2.83 & 2.67 & 1.97 & 2.14 & 0.85 & 0.92 & 0.95 & 1.30 & 1.15 & 1.27 & 1.43 & 1.91 \\
\hline & $60 \%$ & 3.92 & 3.79 & 3.66 & 2.87 & 1.14 & 1.16 & 1.20 & 1.43 & 1.44 & 1.46 & 1.53 & 1.94 \\
\hline \multirow{3}{*}{$\mathrm{Cu}$} & $0 \%$ & 3.25 & 3.7 & 1.84 & 1.98 & 0 & 0 & 0 & 0 & 0 & 0 & 0 & 0 \\
\hline & $30 \%$ & 3.07 & 3.23 & 2.86 & 2.65 & 0.74 & 0.79 & 0.85 & 1.04 & 0.10 & 1.04 & 1.14 & 1.43 \\
\hline & $60 \%$ & 2.47 & 2.46 & 2.55 & 2.70 & 0.80 & 0.84 & 0.88 & 1.02 & 1.12 & 1.18 & 1.23 & 1.39 \\
\hline \multirow{3}{*}{$\mathrm{Pb}$} & $0 \%$ & 1.7 & 2.08 & 2.69 & 1.9 & 0 & 0 & 0 & 0 & 0 & 0 & 0 & 0 \\
\hline & $30 \%$ & 3.07 & 3.33 & 3.31 & 3.66 & 1.09 & 1.21 & 1.31 & 1.82 & 1.45 & 1.58 & 1.71 & 2.31 \\
\hline & $60 \%$ & 2.87 & 2.95 & 2.94 & 2.90 & 0.96 & 1.04 & 1.05 & 1.11 & 1.30 & 1.39 & 1.40 & 1.50 \\
\hline
\end{tabular}

\subsection{Enzymatic Antioxidants and Malondialdehyde (MDA)}

Application of $30 \%$ and $60 \%$ paper sludge substantially improved the activities of enzymatic antioxidants in H. compressa plants (Figure 5). But this increase in the activity of enzymatic antioxidants was more significant with fungal inoculation. Application of F3 treatment $($ A. niger + T. pseudokoningii) significantly increased $(p<0.05)$ the activity of SOD, POD and CAT under both paper sludge concentrations (30\% and 60\%). However, with respect to POD activity, F1 treatment was more effective as compared to F2. Maximum enzymatic antioxidant activity was observed under F3 treatment in both control and paper sludge applications. A similar result was obtained for MDA level in H. compressa. However, the inoculation of different fungal strains considerably decreased the level of MDA in all the treatments (Figure 5). 

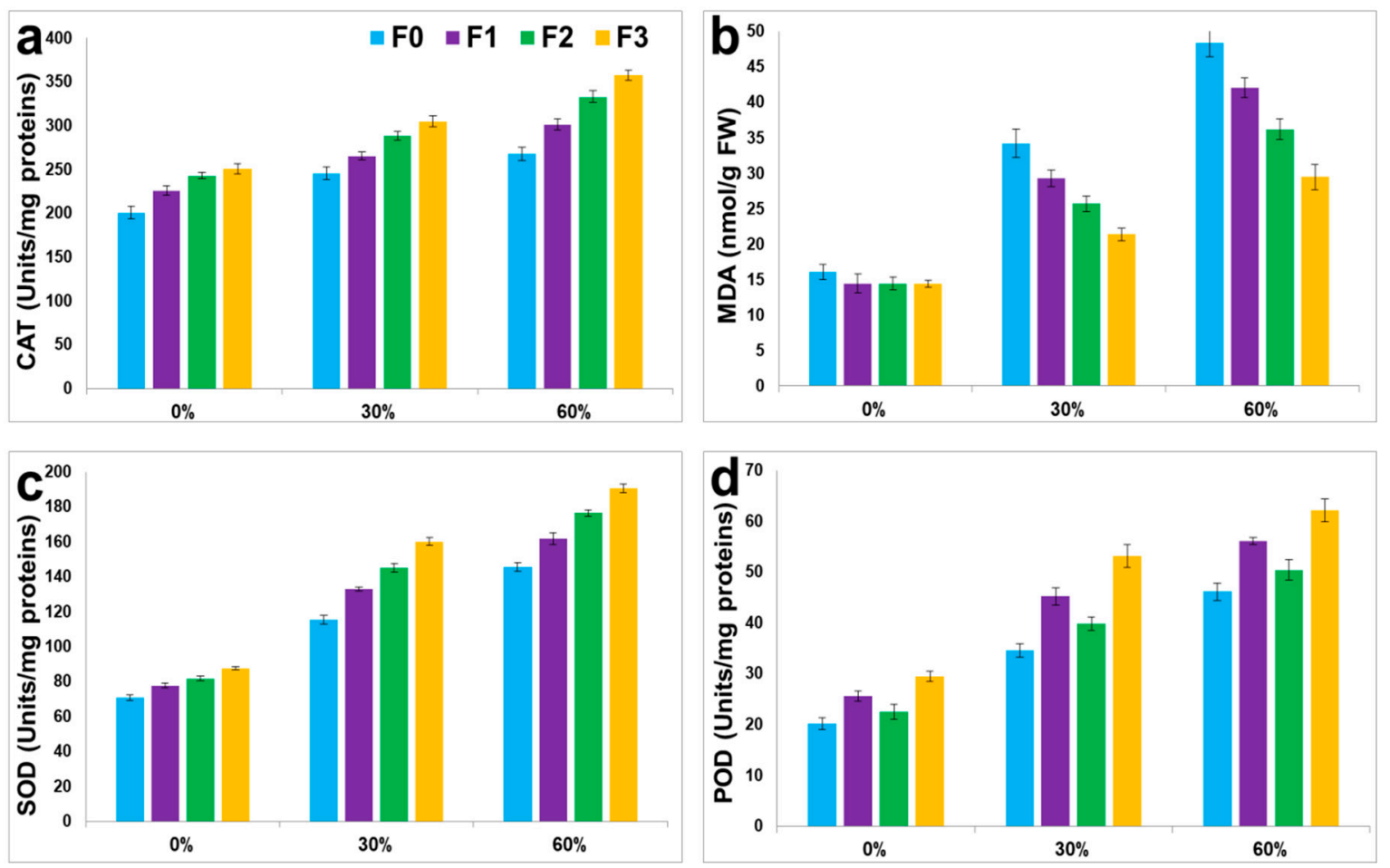

Figure 5. Analysis of antioxidant enzymatic activity and MDA contents in tissues of $H$. compressa plants after $0,30 \%$ and $60 \%$ PS treatment with and without fungal application. The values given above indicate mean of 9 replicates. F0 $=\mathrm{Control}$, F1 = Aspergillus niger, F2 = Trichoderma pseudokoningii, F3 = Aspergillus niger + Trichoderma pseudokoningii.

\subsection{Pearson Correlation and Principal Component Analysis}

To estimate the association between various parameters in H. compressa and fungal treatments supplied with paper sludge, Pearson correlation and principal component analysis (PCA) was executed. Positive and negative Pearson correlations were recorded between different parameters in $H$. compressa subjected to fungal treatments and PS. We observed that PS exerted significant variations in physiological and biochemical attributes antioxidant defense, and mineral nutrients and these were related with plant growth and survival (Figure 6). A negative correlation was observed among shoot length with all other attributes except fresh and dry biomass. Total chlorophyll after 30 days, as well as fresh and dry weights were also negatively correlated under PS application and fungal treatment. Mineral nutrients were positively correlated with antioxidative metabolism and MDA. CAT showed no interaction with chlorophyll and morphological characteristics. Number of roots presented a positive correlation with growth attributes. This correlation analysis showed an obvious relationship between varieties of canola and plant characteristics (Figure 6). This correlational analysis between studied characteristics of $H$. compressa, fungal treatments and PS concentration levels is attested by PCA-Biplot. Figure 7 shows the relationship between concentration levels and studied traits. PC1 and PC2 collectively exhibited 74.7\% and $13.7 \%$ of the variability in data. PC1 explains a very prominent response of $H$. compressa parameters subjected to different concentrations of PS. In the dataset, the distributional aspect of components highlights that PS toxicity in the rooting media was significantly influenced by fungal treatments with respect to their studied parameters (Figure 7). This evidently validates that variables in control plants did not significantly match with the same variables in fungal treated plants under different concentrations of PS. 


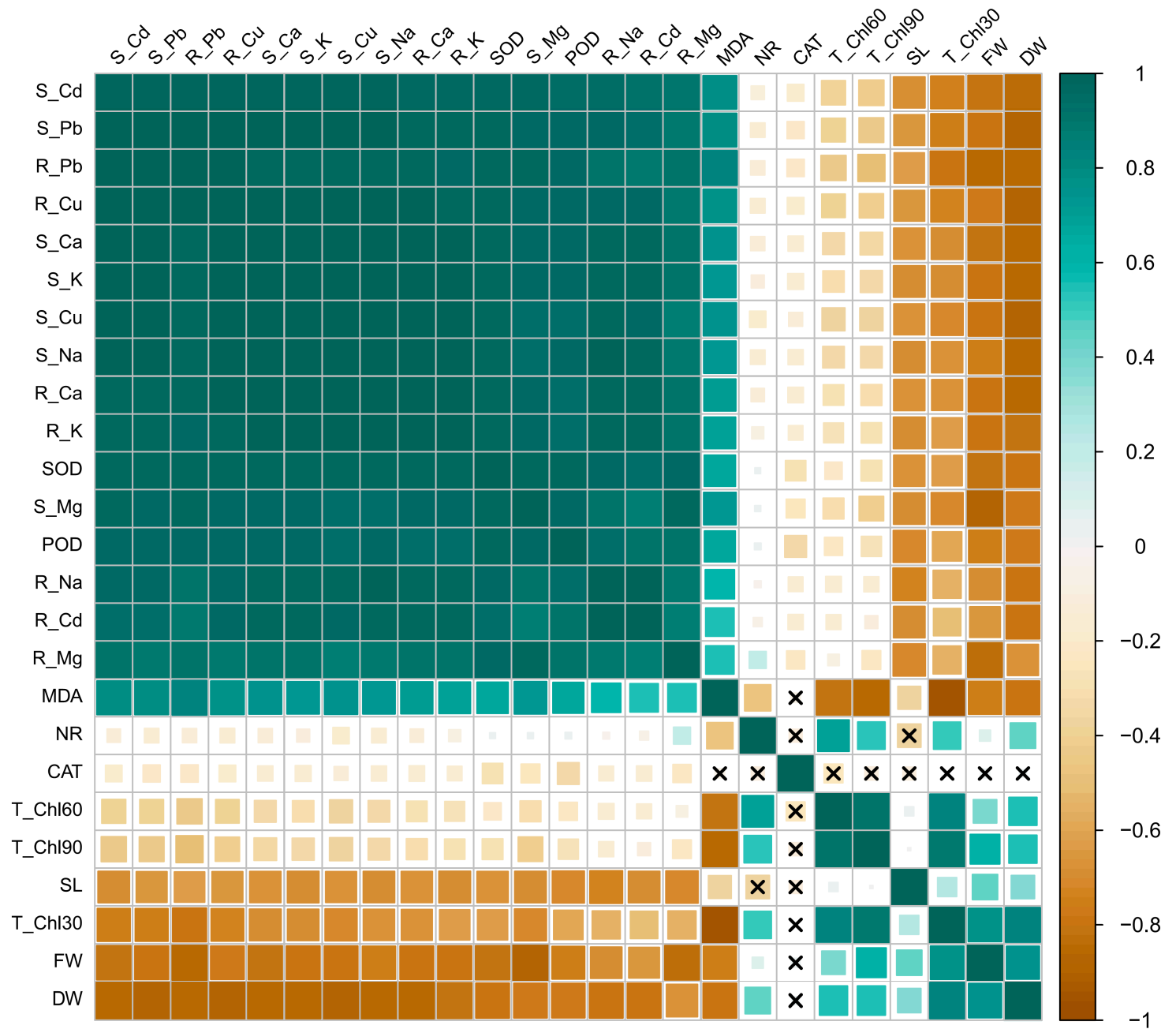

Figure 6. Correlational matrix of all studied attributes in $H$. compressa subjected to different fungal treatments under various concentration of paper sludge. CAT: catalase; DW: dry weight; FW: fresh weight; MDA: malondialdehyde; NR: number of roots; POD: peroxidase; R_Ca: root calcium; R_Cd: root cadmium; R_Cu: root copper; $\mathbf{R} \_K$ : root potassium; $\mathbf{R} \_\mathbf{M g}$ : root magnesium; R_Na: root sodium; R_Pb: root lead; S_Ca: shoot calcium; S_Cd: shoot cadmium; S_Cu: shoot copper; S_K: shoot potassium; S_Mg: shoot magnesium; S_Na: shoot sodium; S_Pb: shoot lead; SL: shoot length; SOD: superoxide; T_Chl: total chlorophyll. 


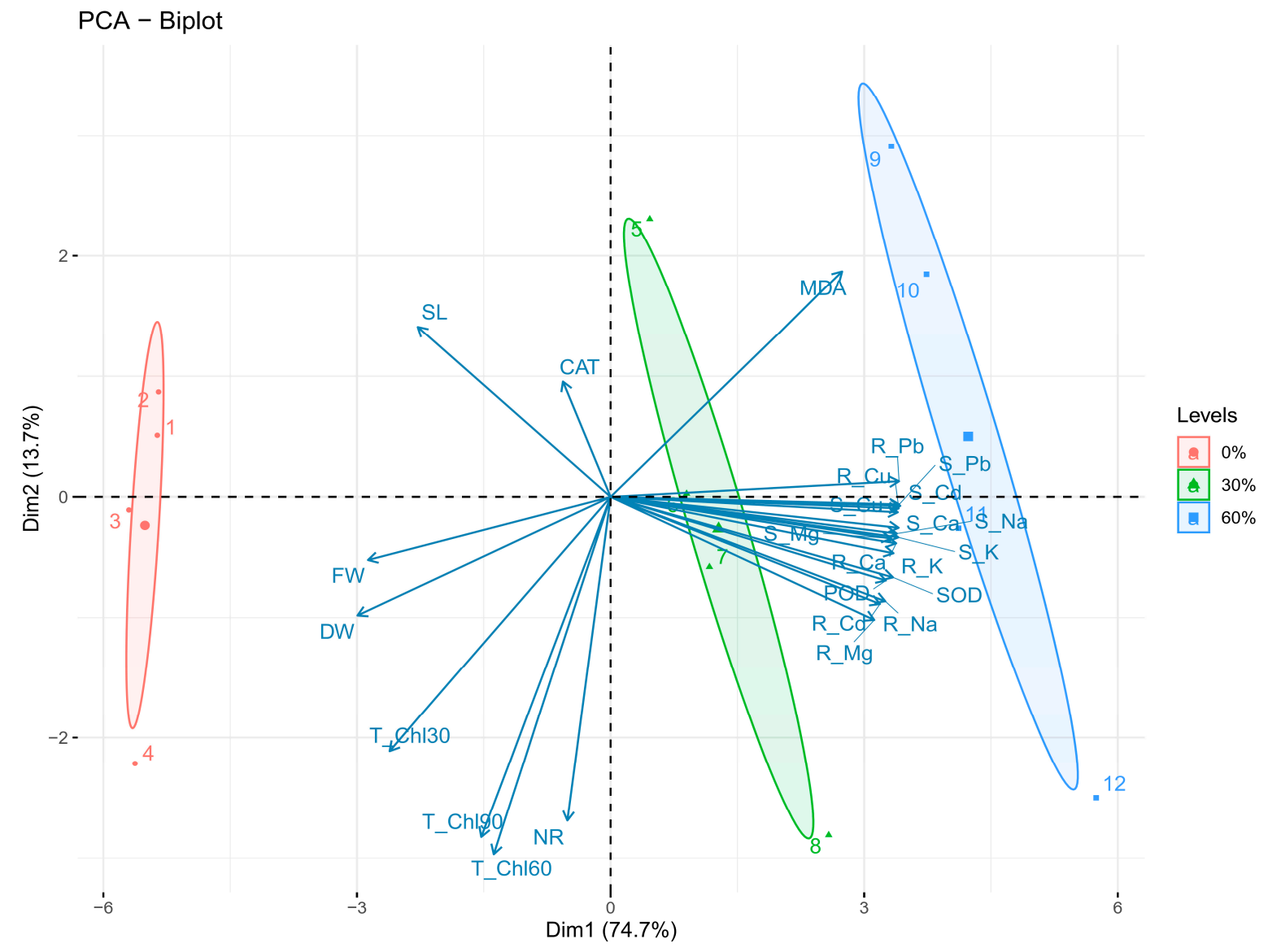

Figure 7. PCA-biplot of all studied attributes in H. compressa subjected to different fungal treatments under various concentration of paper sludge. CAT: catalase; DW: dry weight; FW: fresh weight; MDA: malondialdehyde; NR: number of roots; POD: peroxidase; R_Ca: root calcium; R_Cd: root cadmium; R_Cu: root copper; $\mathbf{R} \_K$ : root potassium; $\mathbf{R} \_\mathbf{M g}$ : root magnesium; R_Na: root sodium; R_Pb: root lead; S_Ca: shoot calcium; S_Cd: shoot cadmium; S_Cu: shoot copper; S_K: shoot potassium; S_Mg: shoot magnesium; S_Na: shoot sodium; S_Pb: shoot lead; SL: shoot length; SOD: superoxide; T_Chl: Total chlorophyll.

\section{Discussion}

Fungi can be used to remediate a large number of heavy metals like $\mathrm{Cd}, \mathrm{Cu}, \mathrm{Cr}$, and $\mathrm{Pb}[23,45]$. Aspergillus niger and Trichoderma pseudokoningii have been found in remediation of metal contaminated soils and stabilize plant metabolism [46]. Trichoderma sp. is most commonly isolated from the ground, as they have ability to reduce toxic element and pollutants in our environment. After changes in the physico-chemical properties of soil, due to HM contamination, habitat becomes very suitable for fungal growth [47]. During their growth, fungi secrete weak organic acids that hinders leaching down of HMs [46]. Therefore, use of different fungal types for bio-remediation of polluted soil is a promising technique as compared to use of synthetic compounds. Hence, our results reflect clear changes in growth and metabolism of $H$. compressa after application of $A$. niger and T. psuedokoningii.

The sludge from the paper industry exhibits great variability in its chemical composition [11]. Treated sludge can be used as a soil conditioner or fertilizer because it is rich in organic matter, nitrogen, phosphorus, potassium and many other nutrients required for the plant growth $[2,4,12,13]$. However, sludge contains various pollutants especially toxic HMs in high quantities, as in our study, HM concentrations were quite high and being a source of HMs, it could contribute to environmental pollution [48]. Thus, it is necessary for HM concentrations to be remediated from such kind of wastes (sludges) before their release into the environment. The results of our investigation indicated the 
presence of all pollution parameters in paper sludge, i.e., $\mathrm{pH}, \mathrm{EC}$, chlorides, $\mathrm{BOD}$ and $\mathrm{COD}$ along with all cations and anions. The value of $\mathrm{pH}$ ranged between 8.20 to 8.55 in different PS concentrations and indicated a basic solution. Our finding is directly supported by the report of Torkashv et al. [49]. According to them, paper sludge increased soil $\mathrm{pH}$ in a dose-dependent manner. Similarly, EC value of sludge and salt contents are directly proportional [50]. These high EC values imply higher concentrations of heavy metals in the sludge in a soluble form.

BOD and COD were maximum in $100 \%$ PS while the minimum values were observed in the control (F0). The levels of all essential metals were enhanced significantly in $30 \%$ and $60 \%$ PS concentrations as compared to control (without sludge). The minimum values of cations were observed in control respectively and these were in the order of $\mathrm{Ca}>$ $\mathrm{Na}>\mathrm{K}>\mathrm{Mg}$. The maximum concentration of heavy metals was in the order of $\mathrm{Cu}>$ $\mathrm{Pb}>\mathrm{Cd}$ in paper sludge. Here, we see a clear correspondence between increasing PS levels and soil properties. The rising cations and anions not only perturb chemical nature of soil but also lead to changes in metabolism of plants [28,51-53]. Collectively, these changes in soil and plant attributes exert negative influence not only on plants but also on ecosystem [54,55]. The level of soil pollution directly relates to the initial concentration of $\mathrm{HM}$ in the soil, as well as amount of inorganic and organic compounds. Our application of two fungi, i.e., A. niger and T. pseudokoningii manifested positive changes in soil and H. compressa attributes.

Heavy metals resistant microbes have the ability to survive in metal toxicity and accumulate HMs at higher concentrations [56,57]. We recorded resistance to heavy metals by $A$. niger and T. pseudokoningii isolated from contaminated site. A significantly highest amount of metals was observed in F3 in higher concentration of PS followed by F2 treatment. The minimum uptake of metals was observed in case of control. Trichoderma sp. (F2) was more beneficial by increasing uptake of metal than Aspergillus sp. in F1 treatment. Our stance is advocated by the survival potential of plants as well as microbes. Direct actions of microbes on metals by making them more mobilize to roots and later movement into plant tissues is reflective of positive influence exerted by both fungal species. This shows survival ability of $A$. niger and T. pseudokoningii and potential benefits by decreasing HM from soil and also in terms of plants that accumulate these HMs. These findings are in line with the findings of Medfu-Tarekegn et al. [58]. Indigenous microbial species that are more adapted to heavy metal containments of the environment have more ability of long-term application in wastewater treatment. Such species can be economically more efficient for bioremediation process.

We recorded maximum growth of seedlings, dry weight and total chlorophyll in F3 treatment (A.niger + T. pseudokoningii) as compared to control and other treatments. An increase in chlorophyll content in the sludge grown plants of $H$. compressa was observed in the combined fungal treatment. Such increase in morpho-biochemical parameters is due to reduction in hazards of HMs that were actually detoxified by fungal species. Here, two possible aspects can be seen. Either HMs were immobilized or these were solubilized and plants were protected, in turn, from injuries. We are of the opinion that fungal species made HMs soluble that move inside plants. The findings of Lin, et al. [59] support our results. Investigational evidence recommend an array of fungi that produce organic acids that act as chelates for HM [60]. For instance, gluconic acid, oxalic acid, acetic acid, and malic acids solubilize HM by soil microbes [61,62]. The chlorophyll content was high in control plants as compared to the other concentrations, as it was decreased with increasing concentrations of effluents. A decrease in chlorophyll content may either be due to inhibition of chlorophyll synthesis or its destruction or replacement of $\mathrm{Mg}$ ions [63]. Our stance is also advocated by the fact that hydrophytes have high remediation potential for macronutrients because of their general fast growth and high biomass production. The amount of essential metals in roots and shoots of the plants was recorded in the order of $\mathrm{Ca}>\mathrm{Na}>\mathrm{K}>\mathrm{Mg}$.

$\mathrm{HM}$ tolerant Beauveria caledonica over secreted organic acids and solubilized $\mathrm{Cd}, \mathrm{Cu}$, $\mathrm{Pb}$, and $\mathrm{Zn}$ [64]. Additionally, mycorrhizal fungi produce oxalate crystals that immobilize 
as well as detoxify metals [65]. The hyphae penetrate deeply into the soil aggregates for chelating or adsorbing HM. Presence of elevated concentration of heavy metals in the plants indicates the biomagnification process [66]. A significant amount of sodium was found in shoots of $H$. compressa. In the case of roots, the amount of all essential metals like sodium, calcium and potassium, copper was minimum after 90 days of exposure. However, response was antagonistic as far as $\mathrm{Cd}$ uptake is concerned. Cd uptake was reduced to $1636 \mathrm{mg} \mathrm{kg}^{-1}$ in the shoots and $588 \mathrm{mg} \mathrm{kg}^{-1}$ in the roots after their exposure in $60 \%$ concentration of paper sludge. It can be inferred that fungal species more immobilized $\mathrm{Cd}$ as compared to others and low amount was uptaken by $\mathrm{H}$. compressa. In addition, the absorbed quantity was translocated to shoot system from roots. It has already been on record that HMs are stored/translocated in different hyperaccumulator plants [67,68]. This absorbance and translocation of minerals and HMs is exhibiting growth losses and also reflect the action of fungal species used in this study to minimize damages to plant life.

The most interesting facet of this study is the high accumulation of $\mathrm{Cu}$ in plant tissues as compared to $\mathrm{Pb}$. It is well known that a low amount of $\mathrm{Cu}$ is lethal in comparison with other HMs at the same quantity [69]. H. compressa can be regarded as a new hyperaccumulator of copper especially compared to a few other plants. A translocation factor (TF) lower than 1.0 and higher than 1.0 is a feature of metal excluder and metal accumulator plant species, respectively $[70,71]$. The recorded TF and EC values clearly reflect capacity of this plant to accumulate metal and clean soil. The mainstream effect of combined application of fungal species is also justified by these attributes. Further metal translocation from roots to shoots in different plant species exhibited variation.

The present study reveals that heavy metals concentration in plant parts varied significantly $(p<0.05)$ among the treatments. The maximum concentration of heavy metals was found in F3 as compared to F1 and F2. The study shows that plants are hyperaccumulators and have ability to reduce heavy metal concentrations from the paper sludge. The removal of toxic and beneficial elements from the sludge is possible by using selecting particular plant species or by crop rotation without the addition of any toxic chemicals [72]. Furthermore, the influence of sludge concentrations effects the plant growth positively, which is comparable to the findings recorded by others [73].

\section{Conclusions}

Phytoremediation efficacy of the plants largely depends upon their ability to accumulate heavy metals and the total biomass produced by them. The present study reveals that $\mathrm{HM}$ concentrations in plant tissues varied significantly after exposure to fungal treatments and different paper sludge concentrations. Overall, F3 treatment $(A$. niger $+T$. pseudokoningii) maximized dealing with HMs by $H$. compressa, which displayed remediation capacity of microbes and tolerance ability of $H$. compressa. Hence, the ability of $H$. compressa plants for removing HMs from PS appeared more efficient with fungal treatment. This is a promising arena for bioremediation of soil and water polluted with industrial wastes. Therefore, post-treatment changes in availability, as well as translocation of HMs had very significant effect on plant growth and their survival. This highlights changes in availability and detoxification of the substrate by A. niger and T. pseudokoningii and its inhibiting factors on metal uptake.

Author Contributions: S.A.K.: Investigation; Methodology; Formal analysis; Resources, M.A.: Data curation; Resources; Formal analysis; Visualization; Methodology; Writing—original draft; Writingreview \& editing, M.F.M.: Formal analysis; Writing—original draft; Writing—review \& editing, N.K.: Resources; Validation; Writing-review \& editing, A.T.: Formal analysis; Methodology; Writingreview \& editing, Z.A.S.: Formal analysis; Investigation; Methodology; Resources, A.A.A.-S.: Software; Validation, M.H.: Funding acquisition, Writing-review \& editing, S.A.: Writing-review \& editing, K.A.A.-M.: Data curation; Funding acquisition; Writing—review \& editing, A.N.: Data curation; Project administration; Resources; Writing—original draft; Writing—review \& editing. All authors approved the final version of the manuscript.

Funding: Not applicable. 
Institutional Review Board Statement: Not applicable.

Informed Consent Statement: Not applicable.

Data Availability Statement: Not applicable.

Acknowledgments: The authors extend their appreciation to the University of Education, Lahore, Pakistan for providing lab facilities and constructive environment for experimentation. Authors also extend their appreciation to the Deanship of Scientific Research, King Khalid University for funding this publication work through research group programs under grant number R.G.P. 2/11/42.

Conflicts of Interest: The authors declared no competing interests associated with this manuscript.

\section{References}

1. Aqeel, M.; Khalid, N.; Tufail, A.; Ahmad, R.Z.; Akhter, M.S.; Luqman, M.; Javed, M.T.; Irshad, M.K.; Alamri, S.; Hashem, M.; et al. Elucidating the distinct interactive impact of cadmium and nickel on growth, photosynthesis, metal-homeostasis, and yield responses of mung bean (Vigna radiata L.) varieties. Environ. Sci. Pollut. Res. 2021, 28, 27376-27390. [CrossRef]

2. Khalid, N.; Rizvi, Z.F.; Yousaf, N.; Khan, S.M.; Noman, A.; Aqeel, M.; Latif, K.; Rafique, A. Rising Metals Concentration in the Environment: A Response to Effluents of Leather Industries in Sialkot. Bull. Environ. Contam. Toxicol. 2021, 106, 493-500. [CrossRef]

3. Ali, H.; Khan, E.; Ilahi, I. Environmental chemistry and ecotoxicology of hazardous heavy metals: Environmental persistence, toxicity, and bioaccumulation. J. Chem. 2019, 2019, 6730305. [CrossRef]

4. Seleiman, M.F.; Santanen, A.; Mäkelä, P.S. Recycling sludge on cropland as fertilizer-Advantages and risks. Resour. Conserv. Recy. 2020, 155, 104647. [CrossRef]

5. Titilawo, Y.; Adeniji, A.; Adeniyi, M.; Okoh, A. Determination of levels of some metal contaminants in the freshwater environments of Osun State, Southwest Nigeria: A risk assessment approach to predict health threat. Chemosphere 2018, 211, 834-843. [CrossRef] [PubMed]

6. Yi, Y.; Tang, C.; Yi, T.; Yang, Z.; Zhang, S. Health risk assessment of heavy metals in fish and accumulation patterns in food web in the upper Yangtze River, China. Ecotoxicol. Environ. Saf. 2017, 145, 295-302. [CrossRef]

7. Shahid, M.J.; Ali, S.; Shabir, G.; Siddique, M.; Rizwan, M.; Seleiman, M.F.; Afzal, M. Comparing the performance of four macrophytes in bacterial assisted floating treatment wetlands for the removal of trace metals $(\mathrm{Fe}, \mathrm{Mn}, \mathrm{Ni}, \mathrm{Pb}$, and $\mathrm{Cr}$ ) from polluted river water. Chemosphere 2020, 243, 125353. [CrossRef] [PubMed]

8. Madan, S.; Sachan, P.; Singh, U. A review on bioremediation of pulp and paper mill effluent â€ "An alternative to conventional remedial technologies. J. Appl. Nat. Sci. 2018, 10, 367-374. [CrossRef]

9. Noman, A.; Hameed, M.; Ali, Q.; Aqeel, M. Foliar tissue architectural diversity among three species of genus Hibiscus for better adaptability under industrial environment. Int. J. Environ. Sci. 2012, 2, 2212-2222.

10. Khalid, N.; Noman, A.; Aqeel, M.; Masood, A.; Tufail, A. Phytoremediation potential of Xanthium strumarium for heavy metals contaminated soils at roadsides. Int. J. Environ. Sci. Technol. 2019, 16, 2091-2100. [CrossRef]

11. Tytła, M.; Widziewicz, K.; Zielewicz, E. Heavy metals and its chemical speciation in sewage sludge at different stages of processing. Environ. Technol. 2016, 37, 899-908. [CrossRef] [PubMed]

12. Singh, R.P.; Agrawal, M. Potential benefits and risks of land application of sewage sludge. Waste Manag. 2008, 28, 347-358. [CrossRef] [PubMed]

13. Ozcan, S.; Tor, A.; Aydin, M.E. Investigation on the levels of heavy metals, polycyclic aromatic hydrocarbons, and polychlorinated biphenyls in sewage sludge samples and ecotoxicological testing. Clean-Soil Air Water 2013, 41, 411-418. [CrossRef]

14. Seleiman, M.F.; Santanen, A.; Stoddard, F.L.; Mäkelä, P. Feedstock quality and growth of bioenergy crops fertilized with sewage sludge. Chemosphere 2012, 89, 1211-1217. [CrossRef]

15. Ghattas, A.-K.; Fischer, F.; Wick, A.; Ternes, T.A. Anaerobic biodegradation of (emerging) organic contaminants in the aquatic environment. Water Res. 2017, 116, 268-295. [CrossRef] [PubMed]

16. Ojuederie, O.B.; Babalola, O.O. Microbial and plant-assisted bioremediation of heavy metal polluted environments: A review. Int J. Environ. Res. Public Health 2017, 14, 1504. [CrossRef]

17. Dixit, R.; Malaviya, D.; Pandiyan, K.; Singh, U.B.; Sahu, A.; Shukla, R.; Singh, B.P.; Rai, J.P.; Sharma, P.K.; Lade, H. Bioremediation of heavy metals from soil and aquatic environment: An overview of principles and criteria of fundamental processes. Sustainability 2015, 7, 2189-2212. [CrossRef]

18. Kumar, A.; Sharma, B. Consequences of Heavy Metals Pollution in the Environment and Their Bioremediation Practices. In Recent Advances in Environmental Management; CRC Press: Boca Raton, FL, USA, 2018; pp. 253-279.

19. Yan, A.; Wang, Y.; Tan, S.N.; Mohd Yusof, M.L.; Ghosh, S.; Chen, Z. Phytoremediation: A promising approach for revegetation of heavy metal-polluted land. Front. Plant Sci. 2020, 11, 359. [CrossRef]

20. Senneca, O.; Cerciello, F.; Russo, C.; Wütscher, A.; Muhler, M.; Apicella, B. Thermal treatment of lignin, cellulose and hemicellulose in nitrogen and carbon dioxide. Fuel 2020, 271, 117656. [CrossRef]

21. Sun, S.; Zhu, J.; Zheng, Z.; Li, J.; Gan, M. Biosynthesis of $\beta$-cyclodextrin modified Schwertmannite and the application in heavy metals adsorption. Powder Technol. 2019, 342, 181-192. [CrossRef] 
22. Gomes, H.I. Phytoremediation for bioenergy: Challenges and opportunities. Environ. Technol. Rev. 2012, 1, 59-66. [CrossRef]

23. Liu, W.T.; Ni, J.C.; Zhou, Q.X. Uptake of heavy metals by trees: Prospects for phytoremediation. Mater. Sci. Forum 2013, 743, 768-781. [CrossRef]

24. Lin, H.; Zhang, X.-H.; Chen, J.; Liang, L.; Liu, L.-H. Phytoremediation potential of Leersia hexandra Swartz of copper contaminated soil and its enhancement by using agronomic management practices. Ecol. Eng. 2019, 127, 561-566. [CrossRef]

25. Sampanpanish, P.; Khaodhiar, S.; Pongsapich, W.; Khan, E. Alternative for chromium removal: Phytoremediation and biosorption with weed plant species in Thailand. Sci. Asia 2007, 33, 353-362. [CrossRef]

26. Sampanpanish, P.; Pongsapich, W.; Khaodhiar, S.; Khan, E. Chromium removal from soil by phytoremediation with weed plant species in Thailand. Water Air Soil Pollut. Focus 2006, 6, 191-206. [CrossRef]

27. Bareen, F.; Khilji, S. Bioaccumulation of metals from tannery sludge by Typha angustifolia L. Af. J. Biotechnol. 2008, 7, 3314-3320.

28. Akhter, N.; Aqeel, M.; Hameed, M.; Alhaithloul, H.A.S.; Alghanem, S.M.; Shahnaz, M.M.; Hashem, M.; Alamri, S.; Khalid, N.; Al-Zoubi, O.M. Foliar architecture and physio-biochemical plasticity determines survival of Typha domingensis pers. Ecotypes in nickel and salt affected soil. Environ. Pollut. 2021, 286, 117316. [CrossRef]

29. Kalve, S.; Sarangi, B.K.; Pandey, R.A.; Chakrabarti, T. Arsenic and chromium hyperaccumulation by an ecotype of Pteris vittata-prospective for phytoextraction from contaminated water and soil. Curr. Sci. 2011, 100, 888-894.

30. Redondo-Gómez, S.; Petenello, M.C.; Feldman, S.R. Growth, nutrient status, and photosynthetic response to diesel-contaminated soil of a cordgrass, Spartina argentinensis. Mar. Pollut. Bull. 2014, 79, 34-38. [CrossRef]

31. Yang, C.; Zhang, X. Hemarhria compressa: Growth behavior and multipurpose. Acta Pratculturae Sin. 2006, 15, $246-248$.

32. Huang, L.; Zhang, X.; Cheng, L.; Chen, L. Evaluation on the Waterlogging Resistance of Whipgrass Germplasm by Subordinate Function. Adv. Sci. Lett. 2012, 7, 328-331. [CrossRef]

33. Bareen, F.-e.; Nazir, A. Metal decontamination of tannery solid waste using Tagetes patula in association with saprobic and mycorrhizal fungi. Environmentalist 2010, 30, 45-53. [CrossRef]

34. Greenburg, A.; Clesceri, L.; Eaton, A. Standard Methods for the Examination of Water and Wastewater, 20th ed.; American Public Health Association: Washington, DC, USA, 1998.

35. Wolf, B. A comprehensive system of leaf analyses and its use for diagnosing crop nutrient status. Commun. Soil Sci. Plant Anal. 1982, 13, 1035-1059. [CrossRef]

36. Giannopolitis, C.N.; Ries, S.K. Superoxide dismutases: II. Purification and quantitative relationship with water-soluble protein in seedlings. Plant Physiol. 1977, 59, 315-318. [CrossRef]

37. Chance, B.; Maehly, A. Assay of catalases and peroxidases. Methods Enzymol. 1955, 2, 764-775. [CrossRef]

38. Cakmak, I.; Horst, W.J. Effect of aluminium on lipid peroxidation, superoxide dismutase, catalase, and peroxidase activities in root tips of soybean (Glycine max). Physiol. Plant. 1991, 83, 463-468. [CrossRef]

39. Gonzaga, M.I.S.; Santos, J.A.G.; Ma, L.Q. Arsenic phytoextraction and hyperaccumulation by fern species. Sci. Agric. 2006, 63, 90-101. [CrossRef]

40. Zhao, F.; Lombi, E.; McGrath, S. Assessing the potential for zinc and cadmium phytoremediation with the hyperaccumulator Thlaspi caerulescens. Plant Soil 2003, 249, 37-43. [CrossRef]

41. Coakley, S.; Cahill, G.; Enright, A.-M.; O’Rourke, B.; Petti, C. Cadmium hyperaccumulation and translocation in Impatiens glandulifera: From foe to friend? Sustainability 2019, 11, 5018. [CrossRef]

42. Kim, H.-Y. Analysis of variance (ANOVA) comparing means of more than two groups. Restor. Dent. Endod. 2014, 39, 74. [CrossRef]

43. Steel, R.G.; Torrie, J.H.; Dickey, D.A. Principles and Procedures of Statistics; McGraw-Hill: New York, NY, USA, $1997 ;$ pp. 4-7.

44. R Development Core Team. R: A Language and Environment for Statistical Computing; R Foundation for Statistical Computing: Vienna, Austria, 2018; Available online: http:/ / www.R-project.org (accessed on 15 March 2021).

45. Liu, J.; Kummerow, C.D.; Elsaesser, G.S. Identifying and analysing uncertainty structures in the TRMM microwave imager precipitation product over tropical ocean basins. Int. J. Remote Sens. 2017, 38, 23-42. [CrossRef]

46. Wasay, S.A.; Barrington, S.F.; Tokunaga, S. Using Aspergillus niger to bioremediate soils contaminated by heavy metals. Bioremed. J. 1998, 2, 183-190. [CrossRef]

47. Hewedy, O.A.; Abdel Lateif, K.S.; Seleiman, M.F.; Shami, A.; Albarakaty, F.M.; M El-Meihy, R. Phylogenetic diversity of Trichoderma strains and their antagonistic potential against soil-borne pathogens under stress conditions. Biology 2020, 9, 189. [CrossRef]

48. Mazurek, R.; Kowalska, J.; Gasiorek, M.; Setlak, M. Micromorphological and physico-chemical analyses of cultural layers in the urban soil of a medieval city-A case study from Krakow, Poland. Catena 2016, 141, 73-84. [CrossRef]

49. Torkashv, A.M.; Haghighat, N.; Shadparvar, V. Effect of paper mill lime sludge as an acid soil amendment. Sci. Res. Essays. 2010, 5, 1302-1306.

50. Khaliq, S.J.A.; Al-Busaidi, A.; Ahmed, M.; Al-Wardy, M.; Agrama, H.; Choudri, B.S. The effect of municipal sewage sludge on the quality of soil and crops. Int. J. Recycl. Org. Waste Agric. 2017, 6, 289-299. [CrossRef]

51. Akhter, N.; Aqeel, M.; Shahnaz, M.M.; Alnusairi, G.S.; Alghanem, S.M.; Kousar, A.; Hashem, M.; Kanwal, H.; Alamri, S.; Ilyas, A. Physiological homeostasis for ecological success of Typha (Typha domingensis Pers.) populations in saline soils. Physiol. Mol. Biol. Plants 2021, 27, 687-701. [CrossRef] [PubMed]

52. Khalid, N.; Hussain, M.; Young, H.S.; Boyce, B.; Aqeel, M.; Noman, A. Effects of road proximity on heavy metal concentrations in soils and common roadside plants in Southern California. Environ. Sci. Pollut. Res. 2018, 25, 35257-35265. [CrossRef] [PubMed] 
53. Noman, A.; Aqeel, M.; Javed, M.; Zafar, S.; Ali, Q.; Islam, W.; Irshad, M.; Buriro, M.; Kanwal, H.; Khalid, N. Histological changes in Hibiscus rosa-sinensis endorse acclimation and phytoremediation of industrially polluted sites. J. Anim. Plant Sci. 2017, 27, 1637-1648.

54. Qasim, M.; Lin, Y.; Dash, C.K.; Bamisile, B.S.; Ravindran, K.; Islam, S.U.; Ali, H.; Wang, F.; Wang, L. Temperature-dependent development of Asian citrus psyllid on various hosts, and mortality by two strains of Isaria. Microb. Pathog. 2018, 119, 109-118. [CrossRef] [PubMed]

55. Qasim, M.; Xiao, H.; He, K.; Omar, M.A.; Hussain, D.; Noman, A.; Rizwan, M.; Khan, K.A.; Al-Zoubi, O.M.; Alharbi, S.A. Host-pathogen interaction between Asian citrus psyllid and entomopathogenic fungus (Cordyceps fumosorosea) is regulated by modulations in gene expression, enzymatic activity and HLB-bacterial population of the host. Comp. Biochem. Physiol. C Toxicol. Pharmacol. 2021, 248, 109112. [CrossRef] [PubMed]

56. Ge, W.; Zamri, D.; Mineyama, H.; Valix, M. Bioaccumulation of heavy metals on adapted Aspergillus foetidus. Adsorption 2011, 17, 901. [CrossRef]

57. Irshad, M.K.; Noman, A.; Wang, Y.; Yin, Y.; Chen, C.; Shang, J. Goethite modified biochar simultaneously mitigates the arsenic and cadmium accumulation in paddy rice (Oryza sativa) L. Environ. Res. 2021, 112238. [CrossRef]

58. Medfu-Tarekegn, M.; Zewdu Salilih, F.; Ishetu, A.I. Microbes used as a tool for bioremediation of heavy metal from the environment. Cogent Food Agric. 2020, 6, 1783174. [CrossRef]

59. Lin, J.; Kroll, C.N.; Nowak, D.J.; Greenfield, E.J. A review of urban forest modeling: Implications for management and future research. Urban For. Urban Green. 2019, 43, 126366. [CrossRef]

60. Seneviratne, M.; Seneviratne, G.; Madawala, H.; Vithanage, M. Role of rhizospheric microbes in heavy metal uptake by plants. In Agro-Environmental Sustainability; Springer: Cham, Switzerland, 2017; pp. 147-163.

61. Gube, M. 4 Fungal molecular response to heavy metal stress. In Biochemistry and Molecular Biology; Springer: Cham, Switzerland, 2016; pp. 47-68.

62. Ullah, A.; Heng, S.; Munis, M.F.H.; Fahad, S.; Yang, X. Phytoremediation of heavy metals assisted by plant growth promoting (PGP) bacteria: A review. Environ. Exp. Bot. 2015, 117, 28-40. [CrossRef]

63. Houri, T.; Khairallah, Y.; Al Zahab, A.; Osta, B.; Romanos, D.; Haddad, G. Heavy metals accumulation effects on the photosynthetic performance of geophytes in Mediterranean reserve. J. King Saud Univ. Sci. 2020, 32, 874-880. [CrossRef]

64. Fomina, M.; Hillier, S.; Charnock, J.; Melville, K.; Alexander, I.J.; Gadd, G. Role of oxalic acid overexcretion in transformations of toxic metal minerals by Beauveria caledonica. Appl. Environ. Microbiol. 2005, 71, 371-381. [CrossRef] [PubMed]

65. Gadd, G.M.; Bahri-Esfahani, J.; Li, Q.; Rhee, Y.J.; Wei, Z.; Fomina, M.; Liang, X. Oxalate production by fungi: Significance in geomycology, biodeterioration and bioremediation. Fungal Biol. Rev. 2014, 28, 36-55. [CrossRef]

66. Tiwari, S.; Dixit, S.; Verma, N. An effective means of biofiltration of heavy metal contaminated water bodies using aquatic weed Eichhornia crassipes. Environ. Monit. Assess. 2007, 129, 253-256. [CrossRef]

67. Liao, S.-W.; Chang, W.-L. Heavy metal phytoremediation by water hyacinth at constructed wetlands in Taiwan. J. Aquat. Plant Manag. 2004, 42, 60-68.

68. Zeng, F.; Mao, Y.; Cheng, W.; Wu, F.; Zhang, G. Genotypic and environmental variation in chromium, cadmium and lead concentrations in rice. Environ. Pollut. 2008, 153, 309-314. [CrossRef] [PubMed]

69. Mishra, V.K.; Tripathi, B. Accumulation of chromium and zinc from aqueous solutions using water hyacinth (Eichhornia crassipes). J. Hazard. Mater. 2009, 164, 1059-1063. [CrossRef]

70. Hossain, M.B.; Rakib, M.R.J.; Jolly, Y.; Rahman, M. Metals uptake and translocation in salt marsh macrophytes, Porteresia sp. from Bangladesh coastal area. Sci. Total Environ. 2021, 764, 144637. [CrossRef]

71. Mahardika, G.; Rinanti, A.; Fachrul, M. Phytoremediation of heavy metal copper $\left(\mathrm{Cu}^{2+}\right)$ by sunflower (Helianthus annuus L.). IOP Conf. Ser. Earth Environ. Sci. 2018, 106, 012120. [CrossRef]

72. Fei, Y.-h.; Zhao, D.; Liu, Y.; Zhang, W.; Tang, Y.-Y.; Huang, X.; Wu, Q.; Wang, Y.-X.; Xiao, T.; Liu, C. Feasibility of sewage sludge derived hydrochars for agricultural application: Nutrients (N, P, K) and potentially toxic elements $(\mathrm{Zn}, \mathrm{Cu}, \mathrm{Pb}, \mathrm{Ni}, \mathrm{Cd})$. Chemosphere 2019, 236, 124841. [CrossRef]

73. Selivanovskaya, S.Y.; Latypova, V. Effects of composted sewage sludge on microbial biomass, activity and pine seedlings in nursery forest. Waste Manag. 2006, 26, 1253-1258. [CrossRef] [PubMed] 